\title{
Cardiovascular risk and testosterone - from subclinical atherosclerosis to lipoprotein function to heart failure
}

\author{
Baris Gencer ${ }^{1} \cdot$ Marco Bonomi $^{2,3}$ (D) $\cdot$ Maria Pia Adorni $^{4} \cdot$ Cesare R. Sirtori $^{5} \cdot$ François Mach $^{1} \cdot$ Massimiliano Ruscica $^{5}$ (I)
}

Accepted: 15 January 2021 / Published online: 22 February 2021

(C) The Author(s) 2021

\begin{abstract}
The cardiovascular (CV) benefit and safety of treating low testosterone conditions is a matter of debate. Although testosterone deficiency has been linked to a rise in major adverse $\mathrm{CV}$ events, most of the studies on testosterone replacement therapy were not designed to assess $\mathrm{CV}$ risk and thus excluded men with advanced heart failure or recent history of myocardial infarction or stroke. Besides considering observational, interventional and prospective studies, this review article evaluates the impact of testosterone on atherosclerosis process, including lipoprotein functionality, progression of carotid intima media thickness, inflammation, coagulation and thromboembolism, quantification of plaque volume and vascular calcification. Until adequately powered studies evaluating testosterone effects in hypogonadal men at increased CV risk are available (TRAVERSE trial), clinicians should ponder the use of testosterone in men with atherosclerotic cardiovascular disease and discuss benefit and harms with the patients.
\end{abstract}

Keywords Atherosclerosis $\cdot$ Hypogonadism $\cdot$ Cardiovascular risk $\cdot$ Cholesterol-efflux capacity $\cdot$ Inflammation $\cdot$ Testosterone

\section{Introduction}

Cardiovascular disease (CVD) is the leading cause of death worldwide, causing over 17 million premature deaths in 2016 [1]. The 2015 World Health Organization mortality registry has reported that CVD kills more women (55\%) than men (45\%), but the proportion of CV deaths before the age of 65 years is larger in men (30\% compared to $26 \%$ in women) [2].

Atherosclerosis is a disease characterized by low-grade and chronic inflammation of the arterial wall which is triggered by

Baris Gencer

baris.gencer@hcuge.ch

Massimiliano Ruscica

massimiliano.ruscica@unimi.it

1 Cardiology Division, Geneva University Hospitals, Geneva, Switzerland

2 Department of Medical Biotechnology and Translational Medicine, Università degli Studi di Milano, Milan, Italy

3 Department of Endocrine and Metabolic Diseases \& Lab. of Endocrine and Metabolic Research, IRCCS Istituto Auxologico Italiano, Milan, Italy

4 Department of Medicine and Surgery-Unit of Neurosciences, University of Parma, Parma, Italy

5 Department of Pharmacological and Biomolecular Sciences, Università degli Studi di Milano, Milan, Italy subendothelial retention of plasma-derived apolipoprotein B (apoB)-containing lipoproteins in the inner layer of the arterial wall, the intima [3]. Besides this lipid-inflammatory etiology, advancing age is itself an established risk factor for CVD, being a component of all major lifetime risk estimate calculators $[4,5]$. In view of the overall increase in life expectancy, evidence-based strategies to prevent CVD are needed in older people. This has drawn attention to the role of sex steroids, particularly testosterone, in cardiovascular health [6]. Declining testosterone levels in older men have been associated with the process of aging called "late-onset hypogonadism" (LOH), [7, 8] a clinical syndrome (usually associated with overweight/obesity requiring a specific rehabilitation) which results from failure of the testes to produce physiological concentrations of testosterone and/or a normal number of spermatozoa due to abnormalities at one or more sites of the hypothalamic-pituitary-testicular axis (HPT).

Testosterone deficiency has been generally linked to a rise in major adverse cardiovascular events (MACEs), especially myocardial infarction (MI) and stroke. However, whether testosterone replacement therapy is beneficial is still debated [9-11]. In 2010 the Food and Drug Administration (FDA) raised concerns on the potentially increased risk of CVD events upon testosterone administration after the premature interruption of the Testosterone in Older Men With Mobility Limitations (TOM) study [12]. Thus, in March 2015, all US commercial testosterone products underwent an FDA- 
mandated label change that restricted the prescription of these medications to men with hypogonadism of known etiology and included a warning about the risk of heart attacks and strokes [13].

Testosterone treatment has been associated with increased wellbeing and improved CV symptoms (angina, claudication). An extensive overview by Oskul et al [14] documented the benefit of testosterone in angina, with raised mean time to 1-mm ST-segment depression on exercise stress testing from 309 seconds at baseline to 343 seconds after 4 weeks and 361 seconds after a 12 -week treatment [15]. Intracoronary testosterone $\left(10^{-10}\right.$ to $\left.10^{-7} \mathrm{~mol} / \mathrm{L}\right)$ in non-hypogonadal men induced a coronary vasodilatation of up to $4.5 \%$ compared to baseline [16]. A similar positive vasodilator activity was reported on brachial arteries following oral testosterone administration [17]. A number of potential mechanisms have been hypothesized, but there is clear evidence that the vasodilator activity is not linked to stimulated nitric oxide [18]. However, in peculiar conditions, as in the case of trans men undergoing hormone-affirming replacement therapy, exposure to testosterone may worsen endothelial function [19].

Finally, it should be considered that in men with coronary heart disease, testosterone deficiency seemed to be a relevant medical condition. As reported in a longitudinal study with a follow-up of $6.9 \pm 2.1$ years, in men with vascular disease, testosterone deficiency was associated with premature death. Levels $<15.1 \mathrm{nmol} / \mathrm{L}$ corresponded to a HR of $1.86(95 \% \mathrm{CI}$ 1.1-3.2) for all-cause mortality and of 2.50 (95\%CI 1.2-5.3) for vascular mortality [20].

Considering that the CV benefit and safety of treating low testosterone conditions have not been definitely proven and controversies still persist, this review article focuses on these controversies and on the potential risks and benefits of testosterone supplementation on CV health.

Background reasons for the so far inconclusive results among studies are (i) differences in dose regimens, (ii) insufficient statistical power for clinical events, or (iii) inclusion criteria allowing the recruitment of healthy asymptomatic men with low or low-normal testosterone. The effects of testosterone on atherosclerosis will be also reviewed in this context, including impact on platelet aggregation [21], highdensity lipoproteins (HDL) functionality and serum capacity to load macrophage with cholesterol [22].

To pursue this aim, by using pubmed.gov, the following algorithm was used: hypogonadism or testosterone replacement therapy or testosterone deficiency AND atherosclerosis AND cholesterol efflux capacity AND cholesterol loading capacity AND coagulation AND inflammation-related atherosclerosis AND lipoproteins AND major adverse cardiovascular events AND QT interval AND subclinical atherosclerosis AND thromboembolism. Relative to clinical studies, the search for literature comprised observational, retrospective, interventional and prospective studies. BG and MR screened titles and full text of papers identified in our search. In the present review, testosterone levels have been reported in different units, as in the original manuscripts. $1 \mathrm{nmol} / \mathrm{L}$ testosterone is equal to $28.842 \mathrm{ng} / \mathrm{dL}$.

\section{Male hypogonadism: definition and classification}

Male hypogonadism historically classified according to either the site of origin (primary/peripheral, secondary/central) or to the gonadotropin levels (hypo- or hyper-gonadotropic) is a clinical syndrome associated with androgen deficiency that originates from a putative damage to the hypothalamus-pituitarytestis (HPT) axis [23, 24]. As summarized in Table 1, primary hypogonadism is typically hypergonadotropic, being related to specific testicular damage resulting from different causes, either congenital or acquired. Conversely, secondary or central hypogonadism are usually hypogonadotropic and caused by congenital or acquired hypothalamic-pituitary damage. Both forms of hypogonadism are indistinctly characterized by low total testosterone, although so far there is no internationally recognized threshold to refer to. Usually, a testosterone value below $8 \mathrm{nmol} / \mathrm{L}$ is considered pathological, whereas a value above $12 \mathrm{nmol} / \mathrm{L}$ is unlikely indicative of hypogonadism [25-29]. Nevertheless, there is a gray area regarding testosterone between 8 and $12 \mathrm{nmol} / \mathrm{L}$ that needs to be carefully considered, as should the calculation of free testosterone, a parameter rated as normal when above $225 \mathrm{pmol} / \mathrm{L}$ [25-29]. The clinical phenotype is strictly related to the onset of the androgenic defect (Table 2). Forms associated with a very early onset (some congenital and genetically determined), also during fetal life, affect the neonatal masculine phenotype and lead to specific signs, such as cryptorchidism (especially bilateral), microphallus and/or hypospadias. Other forms become evident in the peripubertal period and are characterized by absent or incomplete pubertal development. Finally, forms that become manifest only in the adulthood - LOH - are characterized by specific signs and symptoms (hypoactive sexual desire, impaired spontaneous nocturnal/morning erections and/or sexual-related erections) and less specific signs and symptoms (loss of muscle mass, increased body fat, anemia, osteoporosis, depressed mood, decreased vitality, sweating, and hot flushes) $[30,7]$. In adult men older than 40 years, a biochemical finding of secondary or primary hypogonadism is frequent, being present in around $12 \%$ and $2 \%$, respectively, of men of the European general population. According to the majority of Andrology Societies [25-29], and to the Endocrine Society [10], only men with testosterone deficiency that present with specific symptoms can be categorized and treated for true hypogonadism [31]. Forms of late-onset hypogonadotropic hypogonadism may have a genetic predisposition presenting an enrichment of rare variants in genes typically associated with congenital hypogonadotropic hypogonadisms [32]. This is 
Table 1. Causes of male hypogonadism

\begin{tabular}{|c|c|c|}
\hline Hypogonadism & Congenital & Acquired \\
\hline Primary & $\begin{array}{l}\text { - Chromosomal abnormalities (e.g., Klinefelter syndrome, De La } \\
\text { Chapelle syndrome) } \\
\text { - Genetic causes (e.g., Y chromosome microdeletions, androgen } \\
\text { insensitivity, enzymatic defects in androgens biosynthesis, } \\
\text { myotonic dystrophy, LHR/FSHR resistance) } \\
\text { - Congenital anorchia } \\
\text { - Cryptorchidism } \\
\text { - Sertoli cell only syndrome } \\
\text { - Varicocele } \\
\text { - Idiopathic }\end{array}$ & $\begin{array}{l}\text { - Viral orchitis (i.e., mumps) } \\
\text { - Autoimmune } \\
\text { - Testicular trauma } \\
\text { - Testicular torsion } \\
\text { - Iatrogenic (i.e., radio- or chemotherapy, drugs, orchiectomy) } \\
\text { - Secondary varicocele }\end{array}$ \\
\hline Secondary & $\begin{array}{l}\text { - Kallmann syndrome } \\
\text { - Congenital hypogonadotropic } \\
\text { Hypogonadism (CHH) } \\
\text { - Isolated LH or FSH deficiency } \\
\text { - Multiple Pituitary Hormone } \\
\text { Deficiency (MPHDs) } \\
\text { - Prader-Willi syndrome } \\
\text { - Laurence-Moon-Biedl syndrome }\end{array}$ & $\begin{array}{l}\text { - Severe chronic illness (e.g., renal insufficiency, hepatic } \\
\text { insufficiency) } \\
\text { - Hyperprolactinemia } \\
\text { - Excessive exercise } \\
\text { - Nutritional deficiency and starvation } \\
\text { - Obesity/metabolic syndrome/diabetes mellitus } \\
\text { - Acquired MPHDs (e.g., hypothalamic-pituitary lesions, traumatic } \\
\text { brain injuries, vascular brain accidents, hypophysitis, } \\
\text { hemochromatosis, sarcoidosis) } \\
\text { - Drugs (e.g., gonadal steroids, glucocorticoids, opiates, GnRH } \\
\text { analogues) } \\
\text { - Iatrogenic (e.g., pituitary surgery, radiotherapy) } \\
\text { - Idiopathic }\end{array}$ \\
\hline Combined & Late Onset Hypogonadism (LOH) & \\
\hline
\end{tabular}

CHH, Congenital hypogonadotropic hypogonadism; FSH, Follicle Stimulating Hormone; FSHR, Follicle Stimulating Hormone Receptor; GnRH, Gonadotropin-releasing hormone; $L H$, Luteinizing Hormone; LHR, Luteinizing Hormone Receptor; MPHD, Multiple pituitary hormone deficiency

more likely, considering subjects with total testosterone levels below $6 \mathrm{nmol} / \mathrm{L}$ and with an onset before 41 years of age [32]. Moreover, adult-onset hypogonadotropic hypogonadism has been associated with minor pubertal delay, thus, suggesting

Table 2. Signs and symptoms of male hypogonadism according to the onset of the disease

\begin{tabular}{ll}
\hline Age of Onset & Signs \& Symptoms \\
\hline Fetal/Neonatal & Microphallus \\
& Hypospadias \\
& Cryptorchidism \\
Peri-pubertal & Absent or incomplete puberty \\
& Eunuchoid proportions \\
& Underdeveloped genitalia \\
& Erectile dysfunction (spontaneous and/or sex-related) \\
& Hypoactive desire \\
& Infertility \\
& Osteoporosis \\
& Depression/Decreased vitality \\
& Asthenia \\
& Increased body fat/decreased lean mass \\
& Hot flushes/sweating \\
& Anaemia \\
\hline
\end{tabular}

an underlying pre-existing mild impairment of the hypothalamic-pituitary-gonadal (HPG) axis [33-35]. The adult-onset hypogonadotropic hypogonadism phenotype shows nonreproductive clinical manifestations and may share features related to the classical pre-pubertal congenital hypogonadotropic hypogonadism [36], further supporting the hypothesis of a shared origin.

Finally, although not in the remit of the present review article, it is worth mentioning that the treatment of male hypogonadism will be tailored to patients to be treated, taking into account age, specific forms of hypogonadism and any eventual associated comorbidities [37, 38, 10, 29]. Adult-onset forms of male hypogonadotropic hypogonadism can benefit from a dual therapeutic choice that includes the use of exogenous gonadotropins to stimulate not only testicular function but also to allow spermatogenesis and fertility of the patients. The primary forms, characterized by damage of the testis, can only be treated with testosterone replacement therapy. To date, there are several pharmaceutical forms of testosterone approved by the main international drug Agencies, including the Food and Drug Administration and the European Medicines Agency. Testosterone pharmaceutical formulations are usually classified by the route of delivery and can be divided in oral, buccal, nasal, subdermal, transdermal and intramuscular preparations. Specific advantages and disadvantages of each formulation has to be 
considered in the therapeutic decision process after a patientcentered approach that explicit potential risks and benefits [39].

\section{Impact of testosterone in atherosclerosis}

\subsection{Subclinical atherosclerosis}

Carotid intima-media thickness (cIMT), a biomarker of subclinical atherosclerosis positively associated with the risk of CVD events [40, 41], may be influenced by sex hormones. Although not reporting testosterone levels, prominent in this area were the observations by O'Leary who reported that in older adults ( $72.5 \pm 5.5$ years) without a history of CVD, rises in cIMT were directly associated with an increased risk of myocardial infarction and stroke, people in the highest quintile having a 3.9 times higher risk as those in the lowest quintile [42]. This has been confirmed over the years in several cross-sectional studies reporting that in men with symptoms and hormonal levels identifying LOH, IMT of the carotid artery was inversely associated with total testosterone levels $[43,44]$ as was when free testosterone was considered ( $\beta$ : $3.57 ; 95 \%$ CI, -6.34 to -0.80 ) [45].

An important role in this association is played by inflammation. In older people, with high inflammation (high-sensitivity C-reactive protein (hsCRP) $\geq 2 \mathrm{mg} / \mathrm{L}$ ), mean cIMT was significantly higher when testosterone levels were $\leq 3.2 \mathrm{ng} / \mathrm{mL}$ [46]. An opposite conclusion came from the results of the randomized controlled trial (RCT) Testosterone's Effects on Atherosclerosis Progression in Aging Men (TEAAM). The primary endpoint was to evaluate the effect of testosterone administration on the progression of subclinical atherosclerosis in 306 older men (67.6 years) with either low or low-normal testosterone (100-400 $\mathrm{ng} / \mathrm{dL}$ or free testosterone $<50 \mathrm{pg} /$ $\mathrm{mL})$. Three years' administration of testosterone (7.5 g of

Table 3. Impact of testosterone in atherosclerosis

\begin{tabular}{|c|c|c|}
\hline Study & Population's characteristics & Outcomes \\
\hline TEAAM [47] & $\begin{array}{l}306 \mathrm{men} \text { (67.6 years) with testosterone levels of } 100-400 \\
\mathrm{ng} / \mathrm{dL} \text { and free testosterone }<50 \mathrm{ng} / \mathrm{dL} .7 .5 \mathrm{~g} \text { of } 1 \% \\
\text { testosterone were given for } 3 \text { years }\end{array}$ & $\begin{array}{l}\text { - The rate of changes in intima-media thickness was } 0.010 \\
\mathrm{~mm} / \text { year in the placebo group and } 0.012 \mathrm{~mm} / \text { year in } \\
\text { the testosterone group. } \\
\text { - The rate of changes in coronary artery calcium was } 41.4 \\
\text { Agatston units/year in the placebo group and } 31.4 \\
\text { Agatston units/year in the testosterone group. }\end{array}$ \\
\hline TTrials $[51]$ & $\begin{array}{l}170 \text { men }(65 \text { year or older) with testosterone levels }<275 \\
\text { ng/dL. Testosterone } 1 \% \text { gel in a pump bottle was } \\
\text { given for } 12 \text { months }\end{array}$ & $\begin{array}{l}\text { - noncalcified plaque volume raised from } 204 \mathrm{~mm}^{3} \text { to } 232 \\
\mathrm{~mm}^{3} \text { in testosterone group and from } 317 \mathrm{~mm}^{3} \text { to } 325 \\
\mathrm{~mm}^{3} \text { in the placebo group. } \\
\text { - total plaque volume increased from } 272 \mathrm{~mm}^{3} \text { to } 318 \\
\mathrm{~mm}^{3} \text { in the testosterone group and from } 499 \mathrm{~mm}^{3} \text { to } \\
541 \mathrm{~mm}^{3} \text { in the placebo group. } \\
\text { - CAC score dropped from } 255 \text { to } 244 \text { Agatston units in } \\
\text { the testosterone group and raised from } 494 \text { to } 503 \\
\text { Agatston units in the placebo group. }\end{array}$ \\
\hline $\begin{array}{l}\text { Offspring and Third Generation } \\
\text { cohorts of the Framingham } \\
\text { Heart Study [54] }\end{array}$ & $\begin{array}{l}1654 \text { community-dwelling men. Testosterone was } 616 \\
\mathrm{ng} / \mathrm{dL} \text { and free testosterone was } 111 \mathrm{pg} / \mathrm{mL} \text {. }\end{array}$ & $\begin{array}{l}\text { - CAC decreased by }-23 \% \text { every } 100-\mathrm{ng} / \mathrm{dL} \\
\text { between-subjects increase in testosterone. }\end{array}$ \\
\hline $\begin{array}{l}\text { Athero-Express Biobank Study } \\
\text { [55] }\end{array}$ & $\begin{array}{l}611 \text { specimens. Testosterone was } 12.3 \mathrm{nmol} / \mathrm{L} \text { and } \mathrm{E} 2 \\
\text { was } 92.8 \mathrm{pmol} / \mathrm{L}\end{array}$ & $\begin{array}{l}\text { - The testosterone/E2 ratio was negatively associated with } \\
\text { plaque calcification: OR } 0.816,95 \% \mathrm{CI}: 0.666-0.924 \text {. } \\
\text { - In the low testosterone/E2 ratio group, HR for MACE } \\
\text { was } 1.67 \text { (95\%CI: } 1.02-2.76) \text {. In the group with BMI } \geq \\
\left.25 \mathrm{~kg} / \mathrm{m}^{2} \text { the HR was } 2.42 \text { (95\% CI: } 1.09-5.38\right) .\end{array}$ \\
\hline $\begin{array}{l}\text { Idiopatic or genetic (Kalmann } \\
\text { and Klinefelter syndromes) } \\
\text { forms of hypogonadism [22] }\end{array}$ & 20 patients. Testosterone was $4.21 \mathrm{nmol} / \mathrm{L}$ & $\begin{array}{l}\text { - Decrement of total HDL CEC }(-16.2 \%) \text {. } \\
\text { - Rise in serum CLC }(+43 \%) \text {. }\end{array}$ \\
\hline $\begin{array}{l}\text { Database of a commercial clinical } \\
\text { laboratory [69] }\end{array}$ & 10,041 men ( 58 years). Testosterone was $420 \mathrm{ng} / \mathrm{dL}$ & $\begin{array}{l}-1,518 \text { men with testosterone levels }<250 \mathrm{ng} / \mathrm{dL} \text { (vs those } \\
\text { with testosterone levels }>250 \mathrm{ng} / \mathrm{dL} \text { ) had significant } \\
\text { elevated levels of hsCRP, IL- } 6, \mathrm{IL}-17 \mathrm{~A} \text {, and TNF- } \alpha \text {. }\end{array}$ \\
\hline $\begin{array}{l}\text { Randomized, single-blind, } \\
\text { placebo-controlled, crossover } \\
\text { study [74] }\end{array}$ & $\begin{array}{l}\text { Testosterone replacement (Sustanon 100) vs placebo (62 } \\
\pm 9 \text { years). Total testosterone was } 4.4 \pm 1.2 \mathrm{nmol} / \mathrm{L}\end{array}$ & $\begin{array}{l}\text { - Compared to placebo, testosterone reduced TNF } \alpha(-3.1 \\
\quad \pm 8.3 \mathrm{pg} / \mathrm{mL} ; \mathrm{p}=0.01), \mathrm{IL}-1 \beta(-0.14 \pm 0.32 ; \mathrm{p}=0.08) \\
\text { and increased IL-10 }(0.33 \pm 1.8 ; \mathrm{p}=0.01)\end{array}$ \\
\hline
\end{tabular}

CAC, coronary artery calcification; CEC, cholesterol efflux capacity; c-IMT, carotid intima-media thickness; CLC, cholesterol loading capacity; E2, estradiol; hsCRP, high-sensitivity C-reactive protein; HR, hazard ratio; IL, interleukin; OR, odd ratio; TEAAM, Testosterone's Effects on Atherosclerosis Progression in Aging Men; TTrials, Testosterone Trials; TNF- $\alpha$, tumor necrosis factor; $1 \mathrm{nmol} / \mathrm{L}$ testosterone is equal to $28.842 \mathrm{ng} / \mathrm{dL}$ 
$1 \%$ testosterone) led to a nonsignificant rate of change in cIMT: $0.010 \mathrm{~mm} /$ year in the placebo group vs $0.012 \mathrm{~mm} /$ year in the testosterone group. In addition, coronary artery calcium scores did not differ between groups (the mean difference was -10.8 Agatston units/year; 95\%CI -45.7 to $24.2 ; \mathrm{p}=0.54$ ), highlighting the neutral effect of testosterone supplementation compared to placebo in the progression of calcified plaques [47] (Table 3). However, some men with a history of MI or stroke were not enrolled, while those on phosphodiesterase type 5 inhibitors were assigned to the control group [48].

The evaluation of plaque volume in coronary arteries by computed tomographic angiography was one of the goals of the cardiovascular sub-trial of the Testosterone Trials (TTrials) enrolling men 65 year or older with testosterone levels $<250$ $275 \mathrm{ng} / \mathrm{dL}$ on two occasions and self-described symptoms of "male hypogonadism" [49], the noncalcified plaque volume was estimated by the means of low-attenuation plaque, fibrous-fatty plaque, and fibrous plaque; total plaque volume was defined as noncalcified plaque plus dense calcium plaque. Specifically, the TTrials were a set of seven trials aimed at evaluating whether transdermal testosterone treatment of hypogonadal elderly men with low serum testosterone concentrations accompanied by symptoms and objective evidence of impaired mobility and/or reduced libido was effective in improving mobility (Physical Function Trial), sexual function (Sexual Function Trial), fatigue (Vitality Trial), cognitive function (Cognitive Function Trial), hemoglobin (Anemia Trial), bone density (Bone Trial), and coronary artery plaque volume (Cardiovascular Trial) [49]. This last was the last trial to be included and was underpowered to answer the question whether testosterone would increase, decrease or have no effect on cardiovascular events in hypogonadal men. The initial dosage of the testosterone gel was $5 \mathrm{mg}$ with adjustments during the study to attain levels of testosterone in the range $500-800 \mathrm{ng} / \mathrm{dL}$ (reviewed in [50]). One year-treatment with testosterone $(1 \%$ gel in a pump bottle) resulted in a significantly greater increase in noncalcified plaque volume, as assessed by computed tomographic angiography. From baseline, people assigned to testosterone had median values rising from $204 \mathrm{~mm}^{3}$ to $232 \mathrm{~mm}^{3}$, compared to the placebo group (from $317 \mathrm{~mm}^{3}$ to $325 \mathrm{~mm}^{3}$; between groups $\mathrm{p}=0.003$ ) [51]. The increment in noncalcified plaque volume was found in $70 \%$ of men given testosterone, compared to $54 \%$ to those in the placebo group, whereas the proportion of those showing a plaque regression was $27 \%$ in the testosterone group and $45 \%$ in the placebo group [52]. Relative to the secondary endpoint of total plaque volume, this rose from $272 \mathrm{~mm}^{3}$ to $318 \mathrm{~mm}^{3}$ in the testosterone group and from $499 \mathrm{~mm}^{3}$ to $541 \mathrm{~mm}^{3}$ in the placebo group (between groups $\mathrm{p}=0.006)$. Finally, the coronary artery calcification scores were essentially unchanged in both groups (Table 3) [51]. These findings were the object of criticism since it cannot be assumed that a rise in plaque volume will always lead to a limitation of vascular lumen, since vascular remodeling may lead to a maintenance of luminal volume [53].

Vascular calcification was also the object of a crosssectional analysis of data from men in the Offspring Cohort and the Third Generation Cohort of the Framingham Heart Study [54]. Vascular calcification at all sites was negatively associated with testosterone and calculated free testosterone. This trend was attenuated and became statistically nonsignificant after adjustment for traditional CV risk factors (Table 3).

A possible shortcoming in the relationship between sex hormones and CVD risk is that most studies did not look at the ratio between testosterone and estradiol (E2). Yet, it has not been defined whether an interplay, a codependency or rather a synergist effect between these hormones does exist. In a trial that involved the analysis of 611 specimens from male patients who underwent carotid endarterectomy in the Athero-Express Biobank Study, the testosterone/E2 ratio was negatively associated with plaque calcification (Odds Ratio (OR): $0.816 ; 95 \% \mathrm{CI}$ : $0.666-0.924 ; \mathrm{p}=0.044)$, total number of plaque neutrophils ( $\mathrm{p}=$ $0.012)$ ), and interleukin-6 (IL-6) $(\mathrm{p}=0.009)$. An unfavorable inflammatory pattern was found in patients with low testosterone/E2 ratio, i.e., elevated hsCRP levels: $2.81 \mu \mathrm{g} / \mathrm{mL}$ vs $1.22 \mu \mathrm{g} / \mathrm{mL}$ in those with high testosterone/E2 ratio. Finally, low testosterone/E2 ratio independently predicted future major cardiovascular events (hazard ratio (HR) 1.67; 95\%CI: $1.02-$ 2.76, an effect even stronger in obese men (HR 2.42; 95\% CI: 1.09-5.38) (Table 3) [55].

\subsection{Lipoprotein functionality}

The effects of testosterone replacement therapy on cholesterol levels have been investigated by several Authors with no clear conclusions. Testosterone may affect low-density lipoprotein cholesterol (LDL-C) by inhibiting $7 \alpha$-hydroxylase, a key enzyme in bile formation and cholesterol removal [56]; it may reduce high-density lipoprotein cholesterol (HDL-C) levels by raising the activity of hepatic lipase [57] contrary to estrogens [58]. Testosterone is responsible for the hydrolysis of the triacylglycerol component of circulating chylomicrons and very lowdensity lipoproteins (VLDL) [59]. HDL represent a heterogeneous class of lipoproteins with several CV protective functions, the promotion of cholesterol efflux from arterial macrophages of arterial having been most extensively described.

The quantitation of HDL cholesterol efflux capacity (CEC), has been found to be inversely related with incident $\mathrm{CV}$ events, thus leading to the hypothesis that HDL function is a better predictor of CVD risk compared to absolute plasma HDL-C level [60]. When evaluating the relationship between testosterone levels and CV risk associated to changes in lipoprotein functions, Rubinow et al. did not find any differences in HDL CEC after testosterone replacement in older hypogonadal men; conversely, testosterone was associated to an altered HDL proteome, i.e., raised paroxonase-1 and 
fibrinogen- $\alpha$-chain and reduced apolipoprotein A-IV, apolipoprotein C-I and paraoxonase 3 [61]. When a gonadotropinreleasing hormone antagonist was administered to middleaged males, the resulting hypogonadism increased HDL-C without affecting the effluxing capacity [62]. The same pharmacological castration procedure in young healthy men increased both HDL-C and HDL CEC [61]. We have recently demonstrated that in cases of genetic and idiopathic hypogonadisms, very low levels of testosterone were associated with an impaired HDL CEC. This finding was confirmed when the main cellular cholesterol efflux pathways (ATPBinding Cassette transporter A1 and ATP-Binding Cassette transporter G1) were considered individually [22]. Other parameters worthy of consideration are the qualitative and/or compositional modifications of HDL particles, i.e., reduction in $\mathrm{HDL}_{2}$ subtractions in hypogonadal men [63] or changes in the HDL proteomic cargo [61]. HDL CEC only reflects the movement of cholesterol out of cells, whereas the cellular lipid trafficking is bidirectional, being the balance of efflux and influx processes. While it is unquestionable that low density lipoprotein (LDL) is causative in CVD [64], the serum cholesterol loading capacity (CLC) in macrophages has been less extensively explored [65]. In the idiopatic or genetic (Kallmann and Klinefelter syndromes) forms of hypogonadism, CLC is raised independently of LDL plasma concentrations, clearly indicating that the likely rise of arterial wall foam cell formation may contribute to a higher CV risk (Table 3) [22].

\subsection{Inflammation}

Beyond the well-known role of LDL lipids in in atheroma development [66], data from the proof-of-concept Canakinumab Anti-Inflammatory Thrombosis Outcome Study (CANTOS) [67] clearly identified inflammation as a key biological trigger of atherosclerosis. Epidemiological studies evaluating the link between endogenous testosterone and CVD inflammatory markers, mostly CRP and IL-6, reported either an inverse or a lack of association [68]. These discrepancies may rely on the following postulations: (i) the impact of age, i.e., negative associations between testosterone levels and CRP having been reported in relatively younger patients, a lack of association being described in older population groups; (ii) role of the adipose tissue, as when adjusting data for waist circumference or when enrolling obese patients a lack of association was found [14]. Among 10,041 male patients with median age 58 years (range 18-97 years), 1,518 men with testosterone levels $<250 \mathrm{ng} / \mathrm{dL}$ had significantly elevated hsCRP, IL-6, IL-17A, and tumor necrosis factor (TNF)- $\alpha$, when compared to men with testosterone levels $\geq 250 \mathrm{ng} / \mathrm{dL}$ [69]. Finally, a role has been attributed to the NACHT-, LRR- and pyrin domain-containing 3 (NLRP3) pathway [70], a general mediator of arterial tissue inflammation [71]. In C57Bl/6J mice, testosterone administration induced vascular dysfunction through the generation of mitochondrial reactive-oxygen species, an effect not observed in mice lacking NLRP3 [70].

Data from RCTs have generally shown that inflammatory biomarkers linked to $\mathrm{CV}$ risk (TTrial study) were not reduced to a larger extent after testosterone $1 \%$ gel. There were no differences from baseline in d-dimer (a marker of fibrinolysis) changes: $+0.1 \mathrm{mg} / \mathrm{L}$ in both arms; CRP decreased by $0.7 \mathrm{mg} / \mathrm{L}$ with testosterone and $0.1 \mathrm{mg} / \mathrm{L}$ with placebo (difference between groups: $-0.6 \mathrm{mg} / \mathrm{L}, \mathrm{p}=0.11$ ); IL-6 levels were raised by $0.9 \mathrm{pg} / \mathrm{mL}$ with testosterone and by $0.2 \mathrm{pg} / \mathrm{mL}$ with placebo $(\mathrm{p}=0.67)[72]$.

The current interest in the inflammatory causes of acute CVD and the predictive value of circulating biomarkers, particularly hsCRP, has resulted in only limited interventional data on testosterone. In a large sample $(n=2,301)$ of ethnically diverse men aged between 30 and 79 years there was a clear inverse association between CRP and testosterone levels [73]. These findings confirm a prior study [74] in which testosterone replacement $(100 \mathrm{mg}$ testosterone esters) vs placebo over 3 months led to significant reductions of TNF $\alpha$, and IL-1 $\beta$ with a rise of IL-10 (Table 3). Similar findings were reported by Corrales et al [75] in a small study on type 2 diabetic men with androgen deficien$\mathrm{cy}$, where treatment for up to one year with testosterone enanthate ( $150 \mathrm{mg}$ every two weeks) led to a dramatic drop in the production of the cytokines IL- $1 \beta$, TNF- $\alpha$ and IL- 6 by isolated circulating antigen-presenting cells. Further supporting data came from a study that demonstrated that long-term (24 months) testosterone undecanoate administration in patients with metabolic syndrome led to a decrement in the levels of hsCRP and cIMT [76].

The inverse paradigm, i.e., the effect of inflammation on testosterone levels, was the object of an RCT involving 67 men with metabolic syndrome: 33 were given $100 \mathrm{mg}$ of anakinra (a recombinant human IL-1 $\beta$ receptor antagonist) bid for 4 weeks vs placebo. This treatment significantly raised testosterone levels $(1.2 \mathrm{nmol} / \mathrm{L})$ vs placebo $(0.96 \mathrm{nmol} / \mathrm{L} ; 95 \%$ CI $0.29-1.89$ $\mathrm{nmol} / \mathrm{L}$ ). When patients were stratified according to the baseline CRP threshold of $2 \mathrm{mg} / \mathrm{L}$, the effect was more consistent in those with CRP $>2 \mathrm{mg} / \mathrm{dL}$, achieving a significant between-group difference of $2.14 \mathrm{nmol} / \mathrm{L}$ (95\%CI 0.11-4.17). This stepwise increment was more pronounced in patients who reached a reduction $>1 \mathrm{mg} / \mathrm{L}$ after one week, which translated into a rise of 2.8 $\mathrm{nmol} / \mathrm{L}$ in testosterone levels. The human IL- $1 \beta$ receptor antagonist did not, however, rescue severity of symptoms related to hypogonadism, or associated fatigue [77].

\subsection{Coagulation and thromboembolism}

Beyond inflammation and cholesterol accumulation, platelet hyperactivity plays a key role in the genesis and in progression 
of atherothrombosis, stimulating plaque progression and thrombus formation [78]. Confirmations on the hemostatic properties of testosterone came from a study in men (age 62.9 \pm 1.7 ) with mean testosterone levels of 4.49 (4.41-4.71) ng/mL (15.6 (15.316.3) $\mathrm{nM}$ ). In this study, testosterone and dihydrotestosterone were negatively associated with platelet aggregation in response to arachidonic acid or collagen. The testosterone-driven antiplatelet activity is not dose-dependent as it is exerted even at low testosterone concentrations, in the range of hypogonadism [21]. It has been inferred that testosterone inhibits platelet aggregation by stimulating endothelial nitric oxide synthase and vascular endothelial cell growth [79], and confirmation of this came from a study on patients affected by Klinefelter Syndrome. Stimulation of platelets with arachidonic acid (0.2 and 0.4 $\mathrm{mM}$ ) induced an irreversible aggregation in $70 \%$ of Klinefelter Syndrome patients compared with $15 \%$ of controls. These findings were corroborated by the detection of raised levels of circulating 8-iso-prostaglandin F2 $\alpha$ (8-iso-PGF2 $\alpha$ ) and 11dehydro-thromboxane B2 (11-dehydro-TXB2), recognized markers of oxidative stress and platelet activation [80]. Conversely, an earlier RTC had detected a neutral effect of testosterone in a setting of 46 men with chronic stable angina. The administration of physiological doses of supplemental testosterone led to no differences in the levels of plasminogen activator inhibitor-1, fibrinogen, tissue plasminogen activator or hemoglobin concentrations [81].

However, the warning coming from the FDA relative to the association between testosterone therapy and the risk of thromboembolism should not be underestimated. Although there is no doubt on the erythrogenic effect of androgens [82] that leads to an increase in the levels of hemoglobin and hematocrit, the association between testosterone-induced erythrocytosis and subsequent risk of venous thromboembolism remains doubtful. No increment of venous thromboembolism was found in two meta-analyses (OR 1.9 (95\%CI 0.75-5.17) [83] and OR 1.41 (95\%CI 0.96-2.07) [84]), an evidence persisting regardless of the different routes of administration (transdermal or intramuscular) [85]. Conversely, different conclusions were reached by Martinez et al [86] who reported an increased risk of venous thromboembolism within six months of testosterone therapy initiation: a rate ratio of 1.63 (1.12 to 2.37 ) became 1.00 (0.68 to 1.47 ) after six months, and 0.68 (0.43 to 1.07$)$ after treatment cessation [86]. A case-crossover study analyzing data on 39,622 men concluded that testosterone raises venous thromboembolism shortly after treatment initiation. The risk estimates were approximately doubled (OR 2.32, 95\%CI 1.97-2.74) compared to men without hypogonadism, the risk being larger in the first 3 months after initiation. This evidence did not vary by route of exposure [87].

In conclusion, for populations at high CV-risk, it is advisable to check for thrombophilic conditions, antiphospholipid antibody syndrome and prothrombin gene mutations before initiating any form of testosterone treatment. Transdermal or subcutaneous formulations should be strongly considered in at-risk populations [88]. Overall, patients that require testosterone treatment must undergo a complete blood count not only at baseline but also after 3-4 and 12 months, and then annually [82]. Considering that the effect of testosterone on hematocrit is dose-dependent and influenced by age, during testosterone treatment hematocrit should be $<54 \%$ and dose adjustment or temporary treatment interruption has to be considered to keep hematocrit below 54\% [89].

\section{Testosterone replacement therapy and cardiovascular outcomes}

\subsection{Observational and retrospective studies}

Observational studies suggest an association between low endogenous testosterone levels and the increased risk of $\mathrm{CV}$ or all-cause mortality $[14,90]$ (Table 4$)$. The strongest evidence came from a meta-analysis including 12 observational studies comprising 16,184 subjects (mean age 61 years and median follow-up 9.7 years) of which 7 studies specifically related to CVD mortality $(n=11,831)$ [90]. The risk of low testosterone was especially high for men over 60 (Relative Risk (RR) 1.54, 95\% CI 1.28-1.85 when comparing the highest to the lowest tertile). The major limitations of these findings were the absence of a common cut-off for the definition of low testosterone across studies leading to a considerable between-study heterogeneity, and the potential unadjusted confounders [6]. An inverse association between testosterone concentrations and CV mortality was found among 2314 men of the prospective EPIC-Norfolk (European Prospective Investigation into Cancer in Norfolk) study. In this nested-control study, every $6-\mathrm{nmol} / \mathrm{L}$ rise in serum testosterone corresponded to a $17 \%$ reduction of the risk (OR $0.83,95 \%$ CI 0.74 to 0.94 ) [91]. However, the study reported neither levels of calculated nor available free testosterone, a parameter more accurate than total testosterone in obese or diabetic individuals [92]. Similar conclusions were drawn in the Rancho Bernardo Study with a follow-up of 11.8 years. Men with total testosterone levels $<241 \mathrm{ng} / \mathrm{dL}$ had a $38 \%$ higher risk of CVD $(\mathrm{HR}=1.38,95 \% \mathrm{CI} 1.14-1.71)$ [93]. A further confirmation was reported in the larger cohort of MrOS (Osteoporotic Fractures in Men) study $(n=2416)$. High serum testosterone levels $(680 \pm 127 \mathrm{ng} / \mathrm{dL})$ predicted a reduced 5-year risk of $\mathrm{CV}$ events (HR of $0.77,95 \%$ CI 0.60-0.98) [94]. This evidence was also reported in the case of ischemic stroke with extremely low levels of testosterone (173 ng/dL) associated to a HR of 1.34 (95\%CI 1.05-1.72) [95].

Longitudinal studies have also confirmed that symptoms and signs related to hypogonadism are all raised in patients with a history of CVD, although in those at higher CV risk, hypogonadism (total testosterone $<350 \mathrm{ng} / \mathrm{dL}-12 \mathrm{nM}$ ) was 
Table 4. Association between low testosterone levels and total or cardiovascular mortality in population-based cohort studies

\begin{tabular}{|c|c|c|c|c|}
\hline Years & Number of patients & $\begin{array}{l}\text { Mean follow-up } \\
(\mathrm{yr})\end{array}$ & $\begin{array}{l}\text { Mean age } \\
(\mathrm{yr})\end{array}$ & $\begin{array}{l}\text { Results }^{\mathrm{a}} \\
\text { Effect size }(95 \% \mathrm{CI})\end{array}$ \\
\hline Barrett-Connor (1988) [154] & 872 & 12 & 63 & RR 0.87 (0.61-2.08) \\
\hline Smith (2005) [81] & 2323 & 16.5 & 52.1 & RR 1.39 (1.00-1.93) \\
\hline Araujo (2007) [155] & 1686 & 15.3 & 55 & RR $0.81(0.52-1.31)$ \\
\hline Khaw (2007) [91] & 2314 & 7 & 67.3 & RR $1.82(1.17-2.74)$ \\
\hline Laughlin (2008) [93] & 794 & 11.8 & 73.6 & HR 1.38 (1.02-1.85) \\
\hline Haring (2010) [156] & 1954 & 7.2 & 58.7 & RR 4.93 (1.21-20.26) \\
\hline Menke (2010) [157] & 1114 & 8 & 40 & RR 1.24 (0.85-1.78) \\
\hline Vikan (2010) [158] & 1568 & 11.2 & 59.6 & RR 1.09 (0.74-1.63) \\
\hline Haring (2012) [156] & 2039 & 5.5 & $20-79$ & RR $2.05(1.61-2.60)^{\mathrm{b}}$ \\
\hline Pye (2014) [159] & 2599 & 4.3 & $40-79$ & $\operatorname{RR} 2.30(1.20-4.20)^{\mathrm{c}}$ \\
\hline Shores (2014) [100] & 1032 & 9 & 76 & RR $1.03(0.95-1.11)^{\mathrm{d}}$ \\
\hline
\end{tabular}

${ }^{a}$ Relative risk comparing the upper versus the lower tertile of testosterone levels.

${ }^{\mathrm{b}}$ Relative risk comparing the lowest $10^{\text {th }}$ percentile versus the others.

${ }^{\mathrm{c}}$ Relative risk comparing patients with low testosterone levels $(<8 \mathrm{nM})$ vs eugonodal.

${ }^{\mathrm{d}}$ Per standard deviation decrease.

Abbreviations: CI, confidence intervals; HR, hazard ratio; yr, year; RR, relative risk

associated to a lower incidence of new CV events [96]. It is likely that endogenous testosterone level is a marker of general health, and those who are at higher risk of mortality have lower testosterone concentrations.

In a large population of men with acute coronary syndrome, we have investigated the prevalence of low total endogenous testosterone levels $(<300 \mathrm{ng} / \mathrm{dL}$ or $10.4 \mathrm{nM})$ and found it close to $40 \%$ [97]. Observational studies can only show associations but cannot infer about direct causality or differentiate with reverse causality for medical recommendations.

In practice, data from pharmacy claims indicate that testosterone replacement prescriptions have increased over time in elderly men [98]. Among men with androgen deficiency, dispensed testosterone prescriptions are associated with a lower risk of $\mathrm{CV}$ outcomes, i.e., acute myocardial infarction, coronary revascularization, unstable angina, stroke, transient ischemia attack, and sudden cardiac death. Over a median follow-up of 3.2 years, testosterone replacement therapy led to a $33 \%$ reduction in the primary outcome (adjusted HR $=0.67$; 95\% CI 0.62 0.73) [99]. In an observational cohort study of 398 men with androgen deficiency (Northwest Veterans Affairs medical centers), the use of testosterone replacement reduced CV events by $39 \%$ compared to untreated subjects over a follow-up of 3.4 years [100]. A matched-case control analysis, involving 6,355 testosterone treated individuals vs 19,065 free from testosterone therapy individuals, showed no increased risk of MI (HR= $0.84,95 \%$ CI $0.69-1.02$ ), but even a potential decrease in a subset of patients with a high-risk profile [101]. Further evidence on this topic has come from a large retrospective study involving 1,470 patients with low testosterone levels and an history of MI. Testosterone replacement therapy did not increase the recurrence of MI but did reduce all-cause mortality only when testosterone levels were normalized [102]. Interestingly, Etminan et al in a large observational study found no association either between MI and past or current use of testosterone replacement therapy, although an increased risk was described in subjects at first use of testosterone replacement therapy [103].

Retrospective evaluation of 83,010 veterans with documented low testosterone levels showed that prolonged therapy with optimally dosed testosterone appears to be beneficial in terms of CV endpoints. With a mean age of 66 years, men were categorized into those treated with testosterone with normalization (gp1), testosterone treated without normalization (gp2) and not on testosterone [104]. With a follow up ranging between 4.6 and 6.2 years, the comparison between the gp1 and gp3 showed a reduction in the risk of all-cause mortality ( $\mathrm{HR}=$ $0.44,95 \% \mathrm{CI} 0.42-0.46)$, MI ( $\mathrm{HR}=0.76,95 \% \mathrm{CI} 0.63-0.93)$ and stroke (HR= 0.64, 95\%CI 0.43-0.96). Comparison between gp1 and gp2 resulted in a HR of 0.53 (95\% CI $0.50-0.55)$ relative to all-cause mortality, of 0.82 (95\%CI $0.71-0.95)$ relative to the risk of MI, and of 0.70 (95\% CI $0.51-0.96$ ) relative to stroke (HR: 0.70, CI 0.51-0.96) [104].

Opposite conclusions were reported in two retrospective studies $[9,105]$ that have, however, been widely criticized [106]. In the first trial by Veing et al, 8,709 men in the Veterans Healthcare System with low testosterone levels $(<300 \mathrm{ng} / \mathrm{dL}$ or $10.4 \mathrm{nM}$ ) who underwent coronary angiography, the use of testosterone significantly raised adverse 
outcomes (all-cause mortality or hospitalizations for MI or ischemic stroke) over 3 years, compared with men without testosterone replacement [9]. A later official correction reported a $50 \%$ lower rate of CVD events in men on testosterone (10.1\% vs 21.2\%, respectively) [107] [108] This trial was, however, largely criticized as the values of testosterone levels achieved after treatment, i.e., $332.2 \mathrm{ng} / \mathrm{dL}$, lay just within the lower end of the normal range, thus indicating that many men were undertreated. Testosterone patches supplied $2.5 \mathrm{mg} / 24 \mathrm{~h}$, whereas at that time the usual recommended dose was $5 \mathrm{mg}$. Another limitation was that only $60 \%$ of the treatment group had their testosterone levels retested during follow-up, with no knowledge as to whether one prescription meant 30 days or 90 days of treatment [109-111].

Finkle et al. provided similar negative evidence on $\mathrm{CV}$ endpoints following testosterone prescription. By using a large health-care database, cardiac risk was investigated in the 90 days post-testosterone prescription in 55,593 subjects, compared to a larger cohort $(167,279)$ of similar patients receiving phosphodiesterase type 5 inhibitors. The overall rise in coronary risk was $36 \%$, relative risk rising from 0.95 in subjects $<55$ years to 3.43 in those aged $>75$ years. The excess $\mathrm{CV}$ risk in patients below 65 years was restricted to those with pre-existing coronary conditions [105]. One of the major flaws of this study was the absence of a proper control group. The use of phosphodiesterase type 5 inhibitors in heart failure patients has in fact shown to improve left ventricular ejection fraction, diastolic function, exercise tolerance, and overall clinical conditions [112].

In line with these two reports, a population-based cohort study found that the use of testosterone associates with an increased risk of cerebrovascular and cardiovascular diseases, i.e., the HR for the composite outcome was 1.21 ; 95\% CI, 1.00-1.46. The risk was higher in the first 2 years of testosterone use. A second finding was a reverse causality, i.e., a strong protective effect on mortality with current use. Patients who stopped testosterone replacement therapy a few weeks prior to cohort entry had a nearly twofold increased risk of dying (adjusted HR 1.72, 95\%CI 1.21-2.45) [113, 114]. However, criticism was expressed regarding the use of a comparative cohort given $5 \alpha$-reductase inhibitors, or the knowledge that testosterone deficiency itself is a risk for increased $\mathrm{CV}$ events. Indeed, some Authors claimed that data on MACE during the first 12 months could have be linked to hypogonadism rather than to testosterone treatment [115].

Finally, considering that hypogonadism is a comorbidity often present $(25-40 \%)$ in men presenting with type 2 diabetes, an evidence confirmed by genetic studies [116], it is worth mentioning that the influence of baseline testosterone level on type 2 diabetes outcomes were evaluated in a 14-year followup study. During follow-up, the mortality rate was higher in patients with lower total testosterone $(7.6 \pm 2 \mathrm{nmol} / \mathrm{L}) \mathrm{com}-$ pared with normal baseline total testosterone $(16.1 \pm 5$ $\mathrm{nmol} / \mathrm{L}$ ), resulting in $36.1 \%$ of patients with normal baseline testosterone levels dying compared to $55.8 \%$ in those presenting with hypogonadism [117]. Similar conclusions were reached by human genetic studies that revealed that testosterone does play a causal role in the development of certain aspects of metabolic health (such as fasting levels of glucose and body fat levels). In men, each $1 \mathrm{SD}$ increase in testosterone levels corresponded to an OR of 0.86 (95\%CI: 0.76-0.98) to develop type 2 diabetes [118, 119].

Overall, retrospective analyses of data using electronic medical records are generally inconclusive, with major limitations: no randomized allocation, no prospective adjudication of $\mathrm{CV}$ events, confounding by indication (baseline risk of the participants determines the allocation to treatment), heterogeneity of patient populations, and intervention durations or differences in doses.

\subsection{Interventional studies}

A meta-analysis including 27 intervention trials investigating the effects of testosterone treatment on $180 \mathrm{CV}$-related events in 2,994 older men suggested an increased risk of events with the use of testosterone (OR 1.54, 95\% CI 1.09 - 2.18) [120]. The associated risks for testosterone-treated patients were higher in studies not funded by the pharmaceutical industry (OR 2.06, 95\% CI 1.34 - 3.17), compared with industryfunded trials $(0.89,95 \%$ CI $0.50-1.60)$. Mechanistically, some data suggest an impact of testosterone therapy on atherosclerosis. A randomized trial including 138 men 65 years of age or older investigated the effect of testosterone $(\mathrm{N}=73)$ vs placebo $(\mathrm{N}=65)$ on the changes in coronary artery plaque volume over a period of 12 months [51]. At 12 months, the testosterone group had a significantly larger increase in median noncalcified plaque volume [51].

However, definitive data from randomized interventional trials with testosterone replacement therapy in older men are scarce [68]. In the widely quoted study on the effects of testosterone therapy on muscle performance and physical function in older men with mobility limitations (The TOM Trial) [12], 209 men (mean age, 74 years) with serum testosterone $<350 \mathrm{ng} / \mathrm{dL}(12 \mathrm{nM})$ received a large testosterone dose by gel (100 mg testosterone daily), leading to high circulating testosterone levels, i.e., 1,000 ng/dL (34.7 nmol/L) [121]. At the time of the trial, The Endocrine Society was recommending a testosterone goal of 400 to $500 \mathrm{ng} / \mathrm{dL}$ (13.9 to $17.4 \mathrm{nmol} / \mathrm{L}$ ) in such patients [122]. The study was prematurely halted due to a rise in $\mathrm{CV}$ risk (acute coronary syndrome, MI, angioplasty, syncope, atrial fibrillation, peripheral edema, stroke, elevated blood pressure), with an OR of 5.8 (95\% CI 2.0-16.8) [12]. Besides the reasons discussed by the Authors, the results obtained may be the consequence of a rise in plasma estrogen. In view of the conversion of testosterone to estrogens, very high plasma testosterone levels might have led to 
hyperestrogenemia, with a consequently raised risk of $\mathrm{CV}$ events or thrombosis [123]. Another hypothesis accounting for the increased CV risk is raised erythropoiesis driven by testosterone, [124] or a higher degree of physical activity among subjects receiving testosterone supplementation [125]. Short-term physical exertion can precipitate sudden death, stroke, and acute left ventricular dysfunction [126].

The efficacy and safety of testosterone replacement on CV outcomes in older men was also evaluated in a systematic review and meta-analysis of 39 randomized controlled trials and 10 observational studies on testosterone replacement compared with placebo and did not indicate any significant increase in MI, stroke, or global mortality [127]. Secondary analyses have also shown that the increased CV risk upon testosterone treatment is present when frail men or those with body mass index (BMI) $<30 \mathrm{~kg} / \mathrm{m}^{2}$ are considered. Conversely, testosterone treatment seems to be protective in trials enrolling subjects with a mean baseline BMI $>30 \mathrm{~kg} / \mathrm{m}^{2}$ [128]. Overall, there is still no definitive evidence that supports the risk or benefit of testosterone replacement on $\mathrm{CV}$ risk in men with hypogonadism [11].

Similarly, no increase in adverse events was reported in the previously mentioned TEAAM trial [12]. In this study where the carotid IMT and coronary calcium score vascular endpoints were evaluated, no difference was noted between the two groups either for laboratory parameters, sexual function or health-related quality of life.

In this complex scenario, another category that should receive attention is represented by patients with type 2 diabetes, at higher $\mathrm{CV}$ risk. Although epidemiological studies have demonstrated that lower serum testosterone not only is common in men with established type 2 diabetes but also predicts future diabetic risks and increased mortality, the effects of testosterone treatment on androgen deficiency-like clinical features are not conclusive [129]. A placebo- controlled study was carried out in 220 hypogonadal men with type 2 diabetes or the metabolic syndrome treated for 6 months (plus 6 months allowing medication changes) with testosterone gel $2 \%$ vs placebo [130]. A reduction of the homeostasis model assessment-estimated insulin resistance (HOMA-IR) was noted (-15.2\%), together with moderate improvements of glycemia, triglyceridemia and LDL-C, thereby indicating a potentially beneficial effect on insulin resistance, with minimal side effects. Hackett et al [131] reported that testosterone replacement therapy significantly improved $\mathrm{HbAlc}$, total cholesterol, and waist circumference in men with type 2 diabetes, whereas Kalinchenko et al [132] found beneficial changes in weight, BMI and insulin, but without any improvement in serum glucose or lipid profile.

\subsection{A special condition: heart failure}

Special consideration should be given to the value of testosterone in the pathogenesis and progression of heart failure
(HF). Approximately $25 \%$ of men with chronic HF presented with biochemical evidence of testosterone deficiency [133]. Data from the ARIC (Atherosclerosis Risk in Communities) prospective studies (19.2 years of follow-up) showed that low levels of endogenous testosterone were associated with the development of HF [134], a finding in line with studies of Mendelian randomization describing that genetically predicted testosterone was positively associated with the risk of incidence of HF [135]. Cardiac cachexia, a metabolic and functional syndrome with poor prognosis, is characterized by particularly low testosterone levels with an increased risk of HF progression and mortality. The association of testosterone deficiency with myocardial cachexia and progression of HF led to the rationale that correcting testosterone deficiency in HF might be beneficial [133]. In patients with HF, testosterone supplementation was associated with improved exercise function, as well as metabolic parameters such as fasting glucose, fasting insulin, and insulin resistance. No safety concerns were reported in any of the trials; however, data were limited due to small samples and short follow-up (typically 12 weeks) [136]. Conversely, one of the largest prospective studies of testosterone replacement therapy in men with HF demonstrated that over a maximum follow-up of 12 months a significant benefit in functional capacity was obtained by raising the serum levels of testosterone by about $40 \%$. In 76 men with an ejection fraction of $32.5+11 \%$, testosterone administration compared to placebo improved exercise capacity up to 15 $\pm 11 \%$ from baseline. In the active group, total testosterone increased within the normal physiological range (7.5-30 $\mathrm{nmol} / \mathrm{L})$ [137].

Opposite conclusions were, however, reported in a updated meta-analysis showing that in FH patients, testosterone supplementation within a physiological dose-range does not improve exercise tolerance (shuttle walk test or the six-minute walk test), cardiac function, quality of life, or clinical outcome. Of note, a subgroup analysis highlighted that subjects who had reached testosterone levels $\geq 25 \mathrm{nmol} / \mathrm{L}$ benefitted the most in terms of improved exercise capacity, as evaluated by shuttle walk test or the six-minute walk test [138].

Although no studies reported an improvement of systolic cardiac function after testosterone treatment in patients with $\mathrm{HF}$, it is well-known that symptoms of HF are dictated by several factors other than cardiac dysfunction, including peripheral skeletal muscle and insulin resistance, that are potentially improved with testosterone replacement [139].

\subsection{Perspectives}

The Study to Evaluate the Effect of Testosterone Replacement Therapy on the Incidence of Major Adverse Cardiovascular Events and Efficacy Measures in Hypogonadal Men (TRAVERSE) will be the first study on testosterone therapy adequately powered to assess CV events. Initiated in 2018, 
enrollment is planned to end in 2022 (NCT03518034). Briefly, this is a blinded and placebo-controlled study of topical testosterone replacement therapy in symptomatic hypogonadal men with an increased risk of CVD. Six thousand men aged 45 to 80 years with low serum testosterone (< $300 \mathrm{ng} / \mathrm{dL}$ or $10.4 \mathrm{nM}$ ) and at least one sign or symptom of hypogonadism and with evidence of CVD or at increased CVD risk will be randomized for a total duration of 60 months. The primary endpoint will be the first occurrence of a component of the composite of nonfatal MI, nonfatal stroke or death due to $\mathrm{CV}$ causes. The secondary outcomes include cardiac revascularization procedures (percutaneous coronary intervention and coronary artery bypass graft), incidence of prostate cancer, reduced sexual activity, depression, bone fracture, anemia and progression to diabetes [140].

Amid continued uncertainties [141], the aspects to be considered in future trials to succeed could be (1) the safety of different dosage forms (testosterone injections seemed to be associated with a greater risk of $\mathrm{CV}$ events, hospitalization, and deaths compared with topical formulation [142]), (2) the numerosity between treatment groups (at least 17,664 participants in each trial group), and (3) a duration approaching a decade [143].

\section{Conclusion}

Testosterone replacement therapy is commonly prescribed to men and it is therefore essential to gain more reliable safety data for CV outcomes from large and long-term studies. Testosterone replacement therapy is recommended only in symptomatic men with hypogonadism and consistently low serum total testosterone [10]. Nonetheless, the
FDA mandated pharmaceutical companies to add labeling information about a possible increased risk of $\mathrm{CV}$ events, while the European Medicine Agency concluded that there is no consistent evidence of an increased CV risk associated with testosterone therapy in hypogonadal men [11]. While it appears that testosterone replacement therapy does not cause a marked increase in the risk of CV events, another meta-analysis clearly highlighted that none of the studies that evaluated to estimate the risk (15 pharmacoepidemiological and $93 \mathrm{RCT}$ ) had an enough long duration of exposure or were powered to exclude such a risk [128]. The 2020 clinical practice guideline by the American College of Physicians reached the same conclusion, i.e., most of the studies on testosterone replacement were not designed to assess $\mathrm{CV}$ risk and thus excluded men with advanced heart failure or a recent history of myocardial infarction or stroke [144].

On this matter, evaluating the lipid profile (e.g., HDL-C levels) would per se not be enough, rather, it is the functional capacity of lipoproteins that would need to be considered. Since lipid trafficking is a balance between cholesterol efflux and influx, in hypogonadal men proatherogenic lipoproteinassociated changes have been associated with lower cholesterol efflux and increased influx, thus offering an explanation for a potentially increased CV risk (Fig. 1) [22]. Testosterone has also been described as a risk factor for venous thromboembolism due to a rise in (i) hematocrit and blood viscosity, (ii) platelet aggregation, and (iii) thromboxane $\mathrm{A} 2$ concentrations in platelets. Whether or not this is a direct effect driven by testosterone supplementation or due to a rise in the levels of estrogens remains unclear [83].

Among other aspects that are worth of consideration for testosterone treatment, there are the changes in epicardial fat

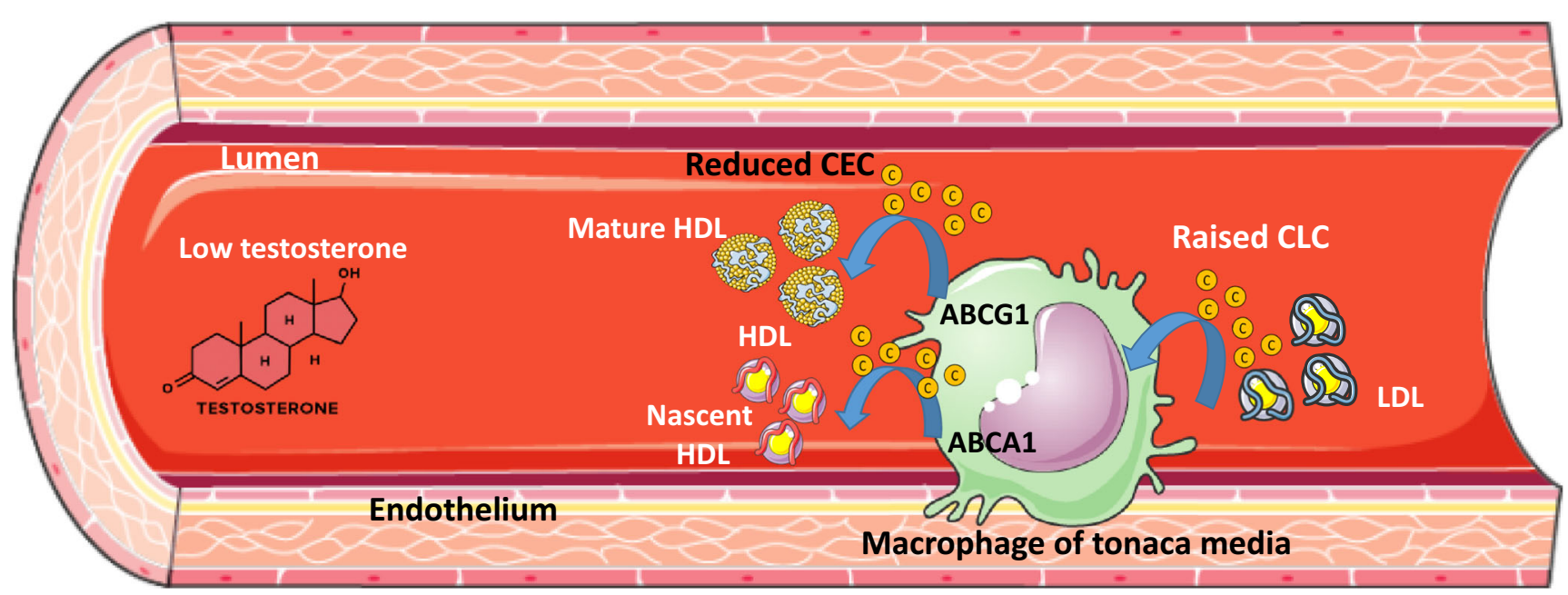

Fig. 1. Effect of low testosterone levels on serum lipoprotein functions. Low circulating testosterone associates with a reduced total HDL CEC from macrophages of the arterial wall by negatively modulating the ABCA1- and ABCG1-mediated efflux pathways, and with a raised serum CLC. ABCA1, ATP-Binding Cassette transporter A1; ABCG1, ATP-Binding Cassette transporter G1; CEC, cholesterol efflux capacity; CLC, cholesterol loading capacity; HDL, high-density lipoprotein; LDL, low-density lipoprotein 
thickness. A rise was detected in subjects with hypogonadal Klinefelter Syndrome, similar to that found in obese agematched euploid subjects [145]. The accumulation of epicardial fat represents, along with visceral fat, a major contributor to CVD risk, above and beyond BMI [146], possibly due to localized release of inflammatory adipokines [147].

Finally, it is worth mentioning that testosterone use is associated also with regulation of ventricular repolarization by shortening the length of the QTc interval. A prolonged heart-rate QT is an independent predictor for cardiac, all-cause mortality [148] and torsades de points ventricular tachycardia [149]. Whether a high number of prolonged QT interval measurements was observed in hypogonadal men [150], the results from the TEAAM trials showed that testosterone replacement attenuates the age-related increase in QT interval duration [151]. Similar conclusions were reached in men aged $\geq 65$ in whom the transdermal administration of testosterone attenuates drug-induced QT lengthening [152]. However, although the precise mechanism linking testosterone and QT interval is poorly understood, the stimulation of endogenous human ether-a-go-go-related gene potassium channels seems one of the most reliable hypotheses [153].

Overall, clinicians must exercise prudence in the use of testosterone in men with prevalent atherosclerotic coronary and cerebrovascular disease. Testosterone replacement in symptomatic elderly men with low testosterone levels should benefit from an individualized approach where uncertainties, risks and benefits of treatment can first be discussed with the patient.

Abbreviations 11-dehydro-TXB2, 11-dehydro-thromboxane B2; 8-isoPGF2 $\alpha$, 8-iso-prostaglandin F2 $\alpha$; Apo, Apolipoprotein; BMI, Body Mass Index; CEC, Cholesterol Efflux Capacity; CHD, Cardiovascular Heart Disease; cIMT, Carotid Intima-Media Thickness; CLC, Cholesterol Loading Capacity; CV, Cardiovascular; CVD, Cardiovascular Disease; E2, Estradiol; FDA, Food and Drug Administration; HDL, High-Density Lipoprotein; HDL-C, HighDensity Lipoprotein-Cholesterol; HF, Heart Failure; HOMA-IR, Homeostasis Model Assessment-Estimated Insulin Resistance; HPG, hypothalamic-pituitary-gonadal; HPT, Hypothalamus-Pituitary-Testis; HR, Hazard Ratio; hsCRP, High-sensitivity C-Reactive Protein; IL, Interleukin; LDL, Low-Density Lipoprotein; LDL-C, Low-Density Lipoprotein-Cholesterol; LOH, Late-Onset Hypogonadism; LRR, Leucine-Rich Repeat; MACEs, Major Adverse Cardiovascular Events; MI, Myocardial Infarction; NLRP3, NACHT-, LRR- and pyrin domaincontaining protein 3; OR, Odds Ratio; RCT, Randomized Controlled Trial; RR, Relative Risk; TNF, Tumor Necrosis Factor; VLDL, Very Low-Density Lipoprotein

Clinical Trial Acronyms ARIC, Atherosclerosis Risk in Communities; CANTOS, Canakinumab Anti-Inflammatory Thrombosis Outcome Study; MrOS, Osteoporotic Fractures in Men; TEAAM, Testosterone Effects on Atherosclerosis in Aging Men; TOM, Testosterone in Older Men With Mobility Limitations; TRAVERSE, Testosterone Replacement Therapy on the Incidence of Major Adverse Cardiovascular Events and Efficacy Measures in Hypogonadal Men; TTrials, Testosterone Trials
Authors' contributions $\mathrm{BG}$, and MR conceived the topic, wrote and edited the manuscript. MB edited the manuscript and wrote the sections pertaining hypogonadism classification and management. CRS and FM critically reviewed the manuscript. MPA wrote the section pertinent the HDL function and helped in preparing tables and figures.

Funding Open Access funding provided by Università degli Studi di Milano. The research activity of MB on male hypogonadism is partially supported by funds from IRCCS Istituto Auxologico Italiano (Ricerca Corrente funds: O5C202_2012; O5C622_2016)

Code availability (software application or custom code) Not applicable

Data Availability Not applicable

\section{Declarations}

Ethics approval Not applicable

Consent for publication Not applicable

Consent to participate Not applicable

Informed consent Not applicable(It is a review article)

Conflicts of interest BG, MB, MPA, CRS FM and MR declare that there is no conflict of interest.

Open Access This article is licensed under a Creative Commons Attribution 4.0 International License, which permits use, sharing, adaptation, distribution and reproduction in any medium or format, as long as you give appropriate credit to the original author(s) and the source, provide a link to the Creative Commons licence, and indicate if changes were made. The images or other third party material in this article are included in the article's Creative Commons licence, unless indicated otherwise in a credit line to the material. If material is not included in the article's Creative Commons licence and your intended use is not permitted by statutory regulation or exceeds the permitted use, you will need to obtain permission directly from the copyright holder. To view a copy of this licence, visit http://creativecommons.org/licenses/by/4.0/.

\section{References}

1. Mendis S. Global progress in prevention of cardiovascular disease. Cardiovasc Diagn Ther. 2017;7(Suppl 1):S32-S8. https:// doi.org/10.21037/cdt.2017.03.06.

2. Townsend N, Nichols M, Scarborough P, Rayner M. Cardiovascular disease in Europe-epidemiological update 2015. Eur Heart J. 2015;36(40):2696-705. https://doi.org/10.1093/ eurheartj/ehv428.

3. Back M, Yurdagul A Jr, Tabas I, Oorni K, Kovanen PT. Inflammation and its resolution in atherosclerosis: mediators and therapeutic opportunities. Nat Rev Cardiol. 2019;16(7):389-406. https://doi.org/10.1038/s41569-019-0169-2.

4. Grundy SM, Stone NJ, Bailey AL, Beam C, Birtcher KK, Blumenthal RS, et al. 2018 AHA/ACC/AACVPR/AAPA/ABC/ ACPM/ADA/AGS/APhA/ASPC/NLA/PCNA Guideline on the Management of Blood Cholesterol: Executive Summary: A Report of the American College of Cardiology/American Heart Association Task Force on Clinical Practice Guidelines. 
Circulation. 2019;139(25):e1046-e81. https://doi.org/10.1161/ CIR.0000000000000624.

5. Authors/Task Force M, Guidelines ESCCfP, Societies ESCNC. 2019 ESC/EAS guidelines for the management of dyslipidaemias: Lipid modification to reduce cardiovascular risk. Atherosclerosis. 2019. doi:https://doi.org/10.1016/j.atherosclerosis.2019.08.014.

6. Gencer B, Mach F. Testosterone: a hormone preventing cardiovascular disease or a therapy increasing cardiovascular events? Eur Heart J. 2016;37(48):3569-75. https://doi.org/10.1093/ eurheartj/ehv439.

7. Nieschlag E. Late-onset hypogonadism: a concept comes of age. Andrology. 2019. https://doi.org/10.1111/andr.12719.

8. Wu FC, Tajar A, Beynon JM, Pye SR, Silman AJ, Finn JD, et al. Identification of late-onset hypogonadism in middle-aged and elderly men. N Engl J Med. 2010;363(2):123-35. https://doi.org/10. 1056/NEJMoa0911101.

9. Vigen R, O'Donnell CI, Baron AE, Grunwald GK, Maddox TM, Bradley SM, et al. Association of testosterone therapy with mortality, myocardial infarction, and stroke in men with low testosterone levels. JAMA. 2013;310(17):1829-36. https://doi.org/10. 1001/jama.2013.280386.

10. Bhasin S, Brito JP, Cunningham GR, Hayes FJ, Hodis HN, Matsumoto AM, et al. Testosterone Therapy in Men With Hypogonadism: An Endocrine Society Clinical Practice Guideline. J Clin Endocrinol Metab. 2018;103(5):1715-44. https://doi.org/10.1210/jc.2018-00229.

11. Elagizi A, Kohler TS, Lavie CJ. Testosterone and Cardiovascular Health. Mayo Clin Proc. 2018;93(1):83-100. https://doi.org/10. 1016/j.mayocp.2017.11.006.

12. Basaria S, Coviello AD, Travison TG, Storer TW, Farwell WR, Jette AM, et al. Adverse events associated with testosterone administration. N Engl J Med. 2010;363(2):109-22. https://doi.org/ 10.1056/NEJMoa1000485.

13. Administration FaD. FDA Drug Safety Communication: FDA cautions about using testosterone products for low testosterone due to aging; requires labeling change to inform of possible increased risk of heart attack and stroke with use. 2015. https:// www.fda.gov/drugs/drug-safety-and-availability/fda-drug-safetycommunication-fda-cautions-about-using-testosterone-productslow-testosterone-due. Accessed May 18th 2020.

14. Oskui PM, French WJ, Herring MJ, Mayeda GS, Burstein S, Kloner RA. Testosterone and the cardiovascular system: a comprehensive review of the clinical literature. J Am Heart Assoc. 2013;2(6):e000272. https://doi.org/10.1161/JAHA.113.000272.

15. English KM, Steeds RP, Jones TH, Diver MJ, Channer KS. Lowdose transdermal testosterone therapy improves angina threshold in men with chronic stable angina: A randomized, double-blind, placebo-controlled study. Circulation. 2000;102(16):1906-11. https://doi.org/10.1161/01.cir.102.16.1906.

16. Webb CM, McNeill JG, Hayward CS, de Zeigler D, Collins P. Effects of testosterone on coronary vasomotor regulation in men with coronary heart disease. Circulation. 1999;100(16):1690-6. https://doi.org/10.1161/01.cir.100.16.1690.

17. Kang SM, Jang Y, Kim J, Chung N, Cho SY, Chae JS, et al. Effect of oral administration of testosterone on brachial arterial vasoreactivity in men with coronary artery disease. Am J Cardiol. 2002;89(7):862-4. https://doi.org/10.1016/s00029149(02)02202-6.

18. Yue P, Chatterjee K, Beale C, Poole-Wilson PA, Collins P. Testosterone relaxes rabbit coronary arteries and aorta. Circulation. 1995;91(4):1154-60. https://doi.org/10.1161/01.cir. 91.4.1154.

19. Gulanski BI, Flannery CA, Peter PR, Leone CA, Stachenfeld NS. Compromised endothelial function in transgender men taking testosterone. Clin Endocrinol (Oxf). 2020;92(2):138-44. https://doi. org/10.1111/cen.14132.
20. Malkin CJ, Pugh PJ, Morris PD, Asif S, Jones TH, Channer KS. Low serum testosterone and increased mortality in men with coronary heart disease. Heart. 2010;96(22):1821-5. https://doi.org/ 10.1136/hrt.2010.195412.

21. Karolczak K, Konieczna L, Kostka T, Witas PJ, Soltysik B, Baczek $\mathrm{T}$, et al. Testosterone and dihydrotestosterone reduce platelet activation and reactivity in older men and women. Aging (Albany NY). 2018;10(5):902-29. https://doi.org/10. 18632/aging.101438.

22. Adorni MP, Zimetti F, Cangiano B, Vezzoli V, Bernini F, Caruso $D$, et al. High-Density Lipoprotein Function Is Reduced in Patients Affected by Genetic or Idiopathic Hypogonadism. J Clin Endocrinol Metab. 2019;104(8):3097-107. https://doi.org/ 10.1210/jc.2018-02027.

23. Cangiano B, Swee DS, Quinton R, Bonomi M. Genetics of congenital hypogonadotropic hypogonadism: peculiarities and phenotype of an oligogenic disease. Hum Genet. 2020. https://doi.org/ 10.1007/s00439-020-02147-1.

24. Zitzmann M, Aksglaede L, Corona G, Isidori AM, Juul A, T'Sjoen $\mathrm{G}$, et al. European academy of andrology guidelines on Klinefelter Syndrome: Endorsing Organization: European Society of Endocrinology. Andrology. 2020. https://doi.org/10.1111/andr. 12909.

25. Lunenfeld B, Mskhalaya G, Zitzmann M, Arver S, Kalinchenko S, Tishova Y, et al. Recommendations on the diagnosis, treatment and monitoring of hypogonadism in men. Aging Male. 2015;18(1):5-15. https://doi.org/10.3109/13685538.2015. 1004049 .

26. Morales A, Bebb RA, Manjoo P, Assimakopoulos P, Axler J, Collier C, et al. Diagnosis and management of testosterone deficiency syndrome in men: clinical practice guideline. CMAJ. 2015;187(18):1369-77. https://doi.org/10.1503/cmaj.150033.

27. Khera M, Adaikan G, Buvat J, Carrier S, El-Meliegy A, Hatzimouratidis K, et al. Diagnosis and Treatment of Testosterone Deficiency: Recommendations From the Fourth International Consultation for Sexual Medicine (ICSM 2015). J Sex Med. 2016;13(12):1787-804. https://doi.org/10.1016/j.jsxm. 2016.10.009.

28. Yeap BB, Grossmann M, McLachlan RI, Handelsman DJ, Wittert GA, Conway AJ, et al. Endocrine Society of Australia position statement on male hypogonadism (part 1): assessment and indications for testosterone therapy. Med J Aust. 2016;205(4):173-8. https://doi.org/10.5694/mja16.00393.

29. Kwong JCC, Krakowsky Y, Grober E. Testosterone Deficiency: A Review and Comparison of Current Guidelines. J Sex Med. 2019;16(6):812-20. https://doi.org/10.1016/j.jsxm.2019.03.262.

30. Rastrelli G, Corona G, Tarocchi M, Mannucci E, Maggi M. How to define hypogonadism? Results from a population of men consulting for sexual dysfunction. J Endocrinol Invest. 2016;39(4): 473-84. https://doi.org/10.1007/s40618-015-0425-1.

31. Rastrelli G, O'Neill TW, Ahern T, Bartfai G, Casanueva FF, Forti $\mathrm{G}$, et al. Symptomatic androgen deficiency develops only when both total and free testosterone decline in obese men who may have incident biochemical secondary hypogonadism: Prospective results from the EMAS. Clin Endocrinol (Oxf). 2018;89(4):459-69. https://doi.org/10.1111/cen.13756.

32. Cangiano B, Duminuco P, Vezzoli V, Guizzardi F, Chiodini I, Corona $\mathrm{G}$, et al. Evidence for a Common Genetic Origin of Classic and Milder Adult-Onset Forms of Isolated Hypogonadotropic Hypogonadism. J Clin Med. 2019;8(1). https://doi.org/10.3390/jcm8010126.

33. Dwyer AA, Hayes FJ, Plummer L, Pitteloud N, Crowley WF Jr. The long-term clinical follow-up and natural history of men with adult-onset idiopathic hypogonadotropic hypogonadism. J Clin Endocrinol Metab. 2010;95(9):4235-43. https://doi.org/10.1210/ jc.2010-0245. 
34. Gianetti E, Tusset C, Noel SD, Au MG, Dwyer AA, Hughes VA, et al. TAC3/TACR3 mutations reveal preferential activation of gonadotropin-releasing hormone release by neurokinin $\mathrm{B}$ in neonatal life followed by reversal in adulthood. J Clin Endocrinol Metab. 2010;95(6):2857-67. https://doi.org/10.1210/jc.20092320.

35. Zhu J, Choa RE, Guo MH, Plummer L, Buck C, Palmert MR, et al. A shared genetic basis for self-limited delayed puberty and idiopathic hypogonadotropic hypogonadism. J Clin Endocrinol Metab. 2015;100(4):E646-54. https://doi.org/10.1210/jc.20151080.

36. Bonomi M, Vezzoli V, Krausz C, Guizzardi F, Vezzani S, Simoni $\mathrm{M}$, et al. Characteristics of a nationwide cohort of patients presenting with isolated hypogonadotropic hypogonadism (IHH). Eur J Endocrinol. 2018;178(1):23-32. https://doi.org/10.1530/EJE-170065.

37. Boehm U, Bouloux PM, Dattani MT, de Roux N, Dode C, Dunkel L, et al. Expert consensus document: European Consensus Statement on congenital hypogonadotropic hypogonadism-pathogenesis, diagnosis and treatment. Nat Rev Endocrinol. 2015;11(9):547-64. https://doi.org/10.1038/nrendo.2015.112.

38. Isidori AM, Balercia G, Calogero AE, Corona G, Ferlin A, Francavilla S, et al. Outcomes of androgen replacement therapy in adult male hypogonadism: recommendations from the Italian society of endocrinology. J Endocrinol Invest. 2015;38(1):10312. https://doi.org/10.1007/s40618-014-0155-9.

39. La Vignera S, Izzo G, Emerenziani GP, Cannarella R, Condorelli RA, Calogero AE, et al. Male hypogonadism: therapeutic choices and pharmacological management. Minerva Endocrinol. 2020;45(3):189-203. https://doi.org/10.23736/S0391-1977.20. 03195-8.

40. Ruscica M, Castelnuovo S, Macchi C, Gandini S, Mombelli G, Ferri N, et al. Left main coronary wall thickness correlates with the carotid intima media thickness and may provide a new marker of cardiovascular risk. Eur J Prev Cardiol. 2019;26(9):1001-4. https://doi.org/10.1177/2047487318806985.

41. Bahls M, Lorenz MW, Dorr M, Gao L, Kitagawa K, Tuomainen TP, et al. Progression of conventional cardiovascular risk factors and vascular disease risk in individuals: insights from the PROGIMT consortium. Eur J Prev Cardiol. 2019;2047487319877078. https://doi.org/10.1177/2047487319877078.

42. O'Leary DH, Polak JF, Kronmal RA, Manolio TA, Burke GL, Wolfson SK Jr. Carotid-artery intima and media thickness as a risk factor for myocardial infarction and stroke in older adults. Cardiovascular Health Study Collaborative Research Group. N Engl J Med. 1999;340(1):14-22. https://doi.org/10.1056/ NEJM199901073400103.

43. Makinen J, Jarvisalo MJ, Pollanen P, Perheentupa A, Irjala K, Koskenvuo $\mathrm{M}$, et al. Increased carotid atherosclerosis in andropausal middle-aged men. J Am Coll Cardiol. 2005;45(10): 1603-8. https://doi.org/10.1016/j.jacc.2005.01.052.

44. Svartberg J, von Muhlen D, Mathiesen E, Joakimsen O, Bonaa $\mathrm{KH}$, Stensland-Bugge E. Low testosterone levels are associated with carotid atherosclerosis in men. J Intern Med. 2006;259(6): 576-82. https://doi.org/10.1111/j.1365-2796.2006.01637.x.

45. Muller M, van den Beld AW, Bots ML, Grobbee DE, Lamberts SW, van der Schouw YT. Endogenous sex hormones and progression of carotid atherosclerosis in elderly men. Circulation. 2004;109(17):2074-9. https://doi.org/10.1161/01.CIR. 0000125854.51637 .06 .

46. Soisson V, Brailly-Tabard S, Empana JP, Feart C, Ryan J, Bertrand M, et al. Low plasma testosterone and elevated carotid intima-media thickness: importance of low-grade inflammation in elderly men. Atherosclerosis. 2012;223(1):244-9. https://doi.org/ 10.1016/j.atherosclerosis.2012.05.009.
47. Basaria S, Harman SM, Travison TG, Hodis H, Tsitouras P, Budoff M, et al. Effects of Testosterone Administration for 3 Years on Subclinical Atherosclerosis Progression in Older Men With Low or Low-Normal Testosterone Levels: A Randomized Clinical Trial. JAMA. 2015;314(6):570-81. https://doi.org/10. 1001/jama.2015.8881.

48. Rai S, Ramasamy R. Words of Wisdom. Re: Effects of Testosterone Administration for 3 Years on Subclinical Atherosclerosis Progression in Older Men With Low or LowNormal Testosterone Levels: A Randomized Clinical Trial. Eur Urol. 2016;69(2):371-2. https://doi.org/10.1016/j.eururo.2015. 10.060 .

49. Snyder PJ, Ellenberg SS, Cunningham GR, Matsumoto AM, Bhasin S, Barrett-Connor E, et al. The Testosterone Trials: Seven coordinated trials of testosterone treatment in elderly men. Clin Trials. 2014;11(3):362-75. https://doi.org/10.1177/ 1740774514524032.

50. Swerdloff R, Wang C. Reflections on The T Trials. Andrology. 2020. https://doi.org/10.1111/andr.12901.

51. Budoff MJ, Ellenberg SS, Lewis CE, Mohler ER 3rd, Wenger NK, Bhasin S, et al. Testosterone Treatment and Coronary Artery Plaque Volume in Older Men With Low Testosterone. JAMA. 2017;317(7):708-16. https://doi.org/10.1001/jama.2016. 21043.

52. Budoff MJ, Ellenberg SS, Snyder PJ. Changes in Coronary Artery Plaque With Testosterone Therapy-Reply. JAMA. 2017;317(23): 2451. https://doi.org/10.1001/jama.2017.6024.

53. Glagov S, Weisenberg E, Zarins CK, Stankunavicius R, Kolettis GJ. Compensatory enlargement of human atherosclerotic coronary arteries. N Engl J Med. 1987;316(22):1371-5. https://doi. org/10.1056/NEJM198705283162204.

54. Travison TG, O'Donnell CJ, Bhasin S, Massaro JM, Hoffmann U, Vasan RS, et al. Circulating Sex Steroids and Vascular Calcification in Community-Dwelling Men: The Framingham Heart Study. J Clin Endocrinol Metab. 2016;101(5):2160-7. https://doi.org/10.1210/jc.2015-4299.

55. van Koeverden ID, de Bakker M, Haitjema S, van der Laan SW, de Vries JPM, Hoefer IE, et al. Testosterone to oestradiol ratio reflects systemic and plaque inflammation and predicts future cardiovascular events in men with severe atherosclerosis. Cardiovasc Res. 2019;115(2):453-62. https://doi.org/10.1093/cvr/cvy188.

56. Moverare-Skrtic S, Venken K, Andersson N, Lindberg MK, Svensson J, Swanson C, et al. Dihydrotestosterone treatment results in obesity and altered lipid metabolism in orchidectomized mice. Obesity (Silver Spring). 2006;14(4):662-72. https://doi.org/ 10.1038/oby.2006.75.

57. Herbst KL, Amory JK, Brunzell JD, Chansky HA, Bremner WJ. Testosterone administration to men increases hepatic lipase activity and decreases HDL and LDL size in 3 wk. Am J Physiol Endocrinol Metab. 2003;284(6):E1112-8. https://doi.org/10. 1152/ajpendo.00524.2002.

58. Karjalainen A, Heikkinen J, Savolainen MJ, Backstrom AC, Kesaniemi YA. Mechanisms regulating LDL metabolism in subjects on peroral and transdermal estrogen replacement therapy. Arterioscler Thromb Vasc Biol. 2000;20(4):1101-6. https://doi. org/10.1161/01.atv.20.4.1101.

59. Botta M, Maurer E, Ruscica M, Romeo S, Stulnig TM, Pingitore P. Deciphering the role of V200A and N291S mutations leading to LPL deficiency. Atherosclerosis. 2019;282:45-51. https://doi.org/ 10.1016/j.atherosclerosis.2019.01.004.

60. Riggs KA, Rohatgi A. HDL and Reverse Cholesterol Transport Biomarkers. Methodist Debakey Cardiovasc J. 2019;15(1):39-46. https://doi.org/10.14797/mdcj-15-1-39.

61. Rubinow KB, Vaisar T, Tang C, Matsumoto AM, Heinecke JW, Page ST. Testosterone replacement in hypogonadal men alters the 
HDL proteome but not HDL cholesterol efflux capacity. J Lipid Res. 2012;53(7):1376-83. https://doi.org/10.1194/jlr.P026005.

62. Rubinow KB, Vaisar T, Chao JH, Heinecke JW, Page ST. Sex steroids mediate discrete effects on HDL cholesterol efflux capacity and particle concentration in healthy men. J Clin Lipidol. 2018;12(4):1072-82. https://doi.org/10.1016/j.jacl.2018.04.013.

63. Bolu E, Sonmez A, Tapan S, Taslipinar A, Aydogdu A, Meric C, et al. HDL cholesterol subfractions and the effect of testosterone replacement in hypogonadism. Horm Metab Res. 2013;45(6): 443-8. https://doi.org/10.1055/s-0033-1343447.

64. Ference BA, Graham I, Tokgozoglu L, Catapano AL. Impact of Lipids on Cardiovascular Health: JACC Health Promotion Series. J Am Coll Cardiol. 2018;72(10):1141-56. https://doi.org/10. 1016/j.jacc.2018.06.046.

65. Adorni MP, Zimetti F, Puntoni M, Bigazzi F, Sbrana F, Minichilli F, et al. Cellular cholesterol efflux and cholesterol loading capacity of serum: effects of LDL-apheresis. J Lipid Res. 2012;53(5): 984-9. https://doi.org/10.1194/jlr.P024810.

66. Borén J, Chapman MJ, Krauss RM, Packard CJ, Bentzon JF, Binder CJ, et al. Low-density lipoproteins cause atherosclerotic cardiovascular disease: pathophysiological, genetic, and therapeutic insights: a consensus statement from the European Atherosclerosis Society Consensus Panel. Eur Heart J. 2020;41(24):2313-2330. https://doi.org/10.1093/eurheartj/ ehz962.

67. Ridker PM, Everett BM, Thuren T, MacFadyen JG, Chang WH, Ballantyne C, et al. Antiinflammatory Therapy with Canakinumab for Atherosclerotic Disease. N Engl J Med. 2017;377(12):111931. https://doi.org/10.1056/NEJMoa1707914.

68. Gagliano-Juca T, Basaria S. Testosterone replacement therapy and cardiovascular risk. Nat Rev Cardiol. 2019;16(9):555-74. https:// doi.org/10.1038/s41569-019-0211-4.

69. Pastuszak AW, Kohn TP, Estis J, Lipshultz LI. Low Plasma Testosterone Is Associated With Elevated Cardiovascular Disease Biomarkers. J Sex Med. 2017;14(9):1095-103. https:// doi.org/10.1016/j.jsxm.2017.06.015.

70. Alves JV, da Costa RM, Pereira CA, Fedoce AG, Silva CAA, Carneiro FS, et al. Supraphysiological Levels of Testosterone Induce Vascular Dysfunction via Activation of the NLRP3 Inflammasome. Front Immunol. 2020;11:1647. https://doi.org/ 10.3389/fimmu.2020.01647.

71. Ruscica M, Corsini A, Ferri N, Banach M, Sirtori CR. Clinical approach to the inflammatory etiology of cardiovascular diseases. Pharmacol Res. 2020;159:104916. https://doi.org/10.1016/j.phrs. 2020.104916.

72. Mohler ER 3rd, Ellenberg SS, Lewis CE, Wenger NK, Budoff MJ, Lewis MR, et al. The Effect of Testosterone on Cardiovascular Biomarkers in the Testosterone Trials. J Clin Endocrinol Metab. 2018;103(2):681-8. https://doi.org/10.1210/ jc.2017-02243.

73. Kupelian V, Chiu GR, Araujo AB, Williams RE, Clark RV, McKinlay JB. Association of sex hormones and C-reactive protein levels in men. Clin Endocrinol (Oxf). 2010;72(4):527-33. https:// doi.org/10.1111/j.1365-2265.2009.03713.x.

74. Malkin CJ, Pugh PJ, Jones RD, Kapoor D, Channer KS, Jones $\mathrm{TH}$. The effect of testosterone replacement on endogenous inflammatory cytokines and lipid profiles in hypogonadal men. J Clin Endocrinol Metab. 2004;89(7):3313-8. https://doi.org/10.1210/jc. 2003-031069.

75. Corrales JJ, Almeida M, Miralles JM, Orfao A. Persistence of androgenic effects on the production of proinflammatory cytokines by circulating antigen-presenting cells after withdrawal of testosterone treatment in aging type 2 diabetic men with partial androgen deficiency. Fertil Steril. 2009;92(1):311-9. https://doi. org/10.1016/j.fertnstert.2008.05.040.
76. Aversa A, Bruzziches R, Francomano D, Rosano G, Isidori AM, Lenzi A, et al. Effects of testosterone undecanoate on cardiovascular risk factors and atherosclerosis in middle-aged men with late-onset hypogonadism and metabolic syndrome: results from a 24-month, randomized, double-blind, placebo-controlled study. J Sex Med. 2010;7(10):3495-503. https://doi.org/10.1111/j.17436109.2010.01931.x.

77. Ebrahimi F, Urwyler SA, Straumann S, Doerpfeld S, Bernasconi L, Neyer P, et al. IL-1 Antagonism in Men With Metabolic Syndrome and Low Testosterone: A Randomized Clinical Trial. J Clin Endocrinol Metab. 2018;103(9):3466-76. https://doi.org/ 10.1210/jc.2018-00739.

78. Palur Ramakrishnan AV, Varghese TP, Vanapalli S, Nair NK, Mingate MD. Platelet activating factor: A potential biomarker in acute coronary syndrome? Cardiovasc Ther. 2017;35(1):64-70. https://doi.org/10.1111/1755-5922.12233.

79. Campelo AE, Cutini PH, Massheimer VL. Testosterone modulates platelet aggregation and endothelial cell growth through nitric oxide pathway. J Endocrinol. 2012;213(1):77-87. https://doi. org/10.1530/JOE-11-0441.

80. Di Minno MN, Esposito D, Di Minno A, Accardo G, Lupoli G, Cittadini A, et al. Increased platelet reactivity in Klinefelter men: something new to consider. Andrology. 2015;3(5):876-81. https://doi.org/10.1111/andr.12080.

81. Smith AM, English KM, Malkin CJ, Jones RD, Jones TH, Channer KS. Testosterone does not adversely affect fibrinogen or tissue plasminogen activator (tPA) and plasminogen activator inhibitor-1 (PAI-1) levels in 46 men with chronic stable angina. Eur J Endocrinol. 2005;152(2):285-91. https://doi.org/10.1530/ eje.1.01848.

82. Jones SD Jr, Dukovac T, Sangkum P, Yafi FA, Hellstrom WJ. Erythrocytosis and Polycythemia Secondary to Testosterone Replacement Therapy in the Aging Male. Sex Med Rev. 2015;3(2):101-12. https://doi.org/10.1002/smrj.43.

83. Corona G, Dicuio M, Rastrelli G, Maseroli E, Lotti F, Sforza A, et al. Testosterone treatment and cardiovascular and venous thromboembolism risk: what is 'new'? J Investig Med. 2017;65(6):964-73. https://doi.org/10.1136/jim-2017-000411.

84. Houghton DE, Alsawas M, Barrioneuvo P, Tello M, Farah W, Beuschel B, et al. Testosterone therapy and venous thromboembolism: A systematic review and meta-analysis. Thromb Res. 2018;172:94-103. https://doi.org/10.1016/j.thromres.2018.10. 023.

85. Baillargeon J, Urban RJ, Morgentaler A, Glueck CJ, Baillargeon G, Sharma G, et al. Risk of Venous Thromboembolism in Men Receiving Testosterone Therapy. Mayo Clin Proc. 2015;90(8): 1038-45. https://doi.org/10.1016/j.mayocp.2015.05.012.

86. Martinez C, Suissa S, Rietbrock S, Katholing A, Freedman B, Cohen AT, et al. Testosterone treatment and risk of venous thromboembolism: population based case-control study. BMJ. 2016;355:i5968. https://doi.org/10.1136/bmj.i5968.

87. Walker RF, Zakai NA, MacLehose RF, Cowan LT, Adam TJ, Alonso A, et al. Association of Testosterone Therapy With Risk of Venous Thromboembolism Among Men With and Without Hypogonadism. JAMA Intern Med. 2019. https://doi.org/10. 1001/jamainternmed.2019.5135.

88. Ohlander SJ, Varghese B, Pastuszak AW. Erythrocytosis Following Testosterone Therapy. Sex Med Rev. 2018;6(1):7785. https://doi.org/10.1016/j.sxmr.2017.04.001.

89. Barbonetti A, D'Andrea S, Francavilla S. Testosterone replacement therapy. Andrology. 2020. https://doi.org/10.1111/andr. 12774.

90. Araujo AB, Dixon JM, Suarez EA, Murad MH, Guey LT, Wittert GA. Clinical review: Endogenous testosterone and mortality in men: a systematic review and meta-analysis. J Clin Endocrinol 
Metab. 2011;96(10):3007-19. https://doi.org/10.1210/jc.20111137.

91. Khaw KT, Dowsett M, Folkerd E, Bingham S, Wareham N, Luben R, et al. Endogenous testosterone and mortality due to all causes, cardiovascular disease, and cancer in men: European prospective investigation into cancer in Norfolk (EPIC-Norfolk) Prospective Population Study. Circulation. 2007;116(23):2694701. https://doi.org/10.1161/CIRCULATIONAHA.107.719005.

92. Basaria S, Dobs AS. Testosterone making an entry into the cardiometabolic world. Circulation. 2007;116(23):2658-61. https:// doi.org/10.1161/CIRCULATIONAHA.107.740365.

93. Laughlin GA, Barrett-Connor E, Bergstrom J. Low serum testosterone and mortality in older men. J Clin Endocrinol Metab. 2008;93(1):68-75. https://doi.org/10.1210/jc.2007-1792.

94. Ohlsson C, Barrett-Connor E, Bhasin S, Orwoll E, Labrie F, Karlsson MK, et al. High serum testosterone is associated with reduced risk of cardiovascular events in elderly men. The MrOS (Osteoporotic Fractures in Men) study in Sweden. J Am Coll Cardiol. 2011;58(16):1674-81. https://doi.org/10.1016/j.jacc. 2011.07.019.

95. Holmegard HN, Nordestgaard BG, Jensen GB, Tybjaerg-Hansen A, Benn M. Sex Hormones and Ischemic Stroke: A Prospective Cohort Study and Meta-Analyses. J Clin Endocrinol Metab. 2016;101(1):69-78. https://doi.org/10.1210/jc.2015-2687.

96. Corona G, Rastrelli G, Maseroli E, Fralassi N, Sforza A, Forti G, et al. Low testosterone syndrome protects subjects with high cardiovascular risk burden from major adverse cardiovascular events. Andrology. 2014;2(5):741-7. https://doi.org/10.1111/j.20472927.2014.00241.x.

97. Gencer B, Vuilleumier N, Nanchen D, Collet TH, Klingenberg R, Raber L, et al. Prognostic value of total testosterone levels in patients with acute coronary syndromes. Eur J Prev Cardiol. 2019;2047487319853343. https://doi.org/10.1177/ 2047487319853343.

98. Baillargeon J, Urban RJ, Ottenbacher KJ, Pierson KS, Goodwin JS. Trends in androgen prescribing in the United States, 2001 to 2011. JAMA Intern Med. 2013;173(15):1465-6. https://doi.org/ 10.1001/jamainternmed.2013.6895.

99. Cheetham TC, An J, Jacobsen SJ, Niu F, Sidney S, Quesenberry $\mathrm{CP}$, et al. Association of Testosterone Replacement With Cardiovascular Outcomes Among Men With Androgen Deficiency. JAMA Intern Med. 2017;177(4):491-9. https://doi. org/10.1001/jamainternmed.2016.9546.

100. Shores MM, Smith NL, Forsberg CW, Anawalt BD, Matsumoto AM. Testosterone treatment and mortality in men with low testosterone levels. J Clin Endocrinol Metab. 2012;97(6):2050-8. https://doi.org/10.1210/jc.2011-2591.

101. Baillargeon J, Urban RJ, Kuo YF, Ottenbacher KJ, Raji MA, Du $\mathrm{F}$, et al. Risk of Myocardial Infarction in Older Men Receiving Testosterone Therapy. Ann Pharmacother. 2014;48(9):1138-44. https://doi.org/10.1177/1060028014539918.

102. Oni OA, Dehkordi SHH, Jazayeri MA, Sharma R, Sharma M, Masoomi R, et al. Relation of Testosterone Normalization to Mortality and Myocardial Infarction in Men With Previous Myocardial Infarction. Am J Cardiol. 2019;124(8):1171-8. https://doi.org/10.1016/j.amjcard.2019.07.019.

103. Etminan M, Skeldon SC, Goldenberg SL, Carleton B, Brophy JM. Testosterone therapy and risk of myocardial infarction: a pharmacoepidemiologic study. Pharmacotherapy. 2015;35(1): 72-8. https://doi.org/10.1002/phar.1534.

104. Sharma R, Oni OA, Gupta K, Chen G, Sharma M, Dawn B, et al. Normalization of testosterone level is associated with reduced incidence of myocardial infarction and mortality in men. Eur Heart J. 2015;36(40):2706-15. https://doi.org/10.1093/eurheartj/ ehv346.
105. Finkle WD, Greenland S, Ridgeway GK, Adams JL, Frasco MA, Cook MB, et al. Increased risk of non-fatal myocardial infarction following testosterone therapy prescription in men. PLoS One. 2014;9(1):e85805. https://doi.org/10.1371/journal.pone.0085805.

106. Morgentaler A, Miner MM, Caliber M, Guay AT, Khera M, Traish AM. Testosterone therapy and cardiovascular risk: advances and controversies. Mayo Clin Proc. 2015;90(2):224-51. https://doi.org/10.1016/j.mayocp.2014.10.011.

107. Ho PM, Baron AE, Wierman ME. Deaths and cardiovascular events in men receiving testosterone-reply. JAMA. 2014;311(9): 964-5. https://doi.org/10.1001/jama.2014.401.

108. Vigen R. Incorrect Number of Excluded Patients Reported in the Text and Figure. JAMA. 2014;311(9):967. https://doi.org/10. 1001/jama.2014.444.

109. Jones TH, Channer KS. Deaths and cardiovascular events in men receiving testosterone. JAMA. 2014;311(9):962-3. https://doi. org/10.1001/jama.2014.398.

110. Riche DM, Baker WL, Koch CA. Deaths and cardiovascular events in men receiving testosterone. JAMA. 2014;311(9):9634. https://doi.org/10.1001/jama.2014.386.

111. Katz J, Nadelberg R. Deaths and cardiovascular events in men receiving testosterone. JAMA. 2014;311(9):963. https://doi.org/ 10.1001/jama.2014.395.

112. Dupree JM, Ramasamy R, Kovac JR, Langille G, Lipshultz LI. Re: Increased risk of non-fatal myocardial infarction following testosterone therapy prescription in men. Eur Urol. 2014;66(1): 175-6. https://doi.org/10.1016/j.eururo.2014.03.038.

113. Loo SY, Azoulay L, Nie R, Dell'Aniello S, Yu OHY, Renoux C. Cardiovascular and Cerebrovascular Safety of Testosterone Replacement Therapy Among Aging Men with Low Testosterone Levels: A Cohort Study. Am J Med. 2019;132(9): 1069-77 e4. https://doi.org/10.1016/j.amjmed.2019.03.022.

114. Renoux C, Azoulay L, Dell'Aniello S, Yu OHY. The Reply. Am J Med. 2019;132(10):e749. https://doi.org/10.1016/j.amjmed.2019. 06.010 .

115. Traish AM, Hackett G, Miner M, Morgentaler A. Cardiovascular and Cerebrovascular Safety of Testosterone Therapy. Am J Med. 2019;132(10):e748. https://doi.org/10.1016/j.amjmed.2019.04. 042.

116. Flynn E, Tanigawa Y, Rodriguez F, Altman RB, SinnottArmstrong N, Rivas MA. Sex-specific genetic effects across biomarkers. Eur J Hum Genet. 2020. https://doi.org/10.1038/s41431020-00712-w.

117. Malipatil NS, Yadegarfar G, Lunt M, Keevil B, Siddals K, Livingston $\mathrm{M}$, et al. Male hypogonadism: 14-year prospective outcome in 550 men with type 2 diabetes. Endocrinol Diabetes Metab. 2019;2(3):e00064. https://doi.org/10.1002/edm2.64.

118. Ruth KS, Day FR, Tyrrell J, Thompson DJ, Wood AR, Mahajan $\mathrm{A}$, et al. Using human genetics to understand the disease impacts of testosterone in men and women. Nat Med. 2020;26(2):252-8. https://doi.org/10.1038/s41591-020-0751-5.

119. Greenhill C. Genetic analysis reveals role of testosterone levels in human disease. Nat Rev Endocrinol. 2020;16(4):195. https://doi. org/10.1038/s41574-020-0338-8.

120. Xu L, Freeman G, Cowling BJ, Schooling CM. Testosterone therapy and cardiovascular events among men: a systematic review and meta-analysis of placebo-controlled randomized trials. BMC Med. 2013;11:108. https://doi.org/10.1186/1741-7015-11-108.

121. Khoo TK. Adverse events associated with testosterone administration. N Engl J Med. 2010;363(19):1865-6; author reply 6-7. https://doi.org/10.1056/NEJMc1009326.

122. Bhasin S, Cunningham GR, Hayes FJ, Matsumoto AM, Snyder PJ, Swerdloff RS, et al. Testosterone therapy in men with androgen deficiency syndromes: an Endocrine Society clinical practice guideline. J Clin Endocrinol Metab. 2010;95(6):2536-59. https:// doi.org/10.1210/jc.2009-2354. 
123. Phillips GB, Pinkernell BH, Jing TY. The association of hyperestrogenemia with coronary thrombosis in men. Arterioscler Thromb Vasc Biol. 1996;16(11):1383-7. https:// doi.org/10.1161/01.atv.16.11.1383.

124. Hall M. Adverse events associated with testosterone administration. N Engl J Med. 2010;363(19):1866; author reply -7. https:// doi.org/10.1056/NEJMc1009326.

125. Weikert C, Pischon T, Weikert S. Adverse events associated with testosterone administration. N Engl J Med. 2010;363(19):1865; author reply 6-7. https://doi.org/10.1056/NEJMc1009326.

126. Thompson PD, Franklin BA, Balady GJ, Blair SN, Corrado D, Estes NA 3rd, et al. Exercise and acute cardiovascular events placing the risks into perspective: a scientific statement from the American Heart Association Council on Nutrition, Physical Activity, and Metabolism and the Council on Clinical Cardiology. Circulation. 2007;115(17):2358-68. https://doi.org/ 10.1161/CIRCULATIONAHA.107.181485.

127. Alexander GC, Iyer G, Lucas E, Lin D, Singh S. Cardiovascular Risks of Exogenous Testosterone Use Among Men: A Systematic Review and Meta-Analysis. Am J Med. 2017;130(3):293-305. https://doi.org/10.1016/j.amjmed.2016.09.017.

128. Corona G, Rastrelli G, Di Pasquale G, Sforza A, Mannucci E, Maggi M. Testosterone and Cardiovascular Risk: Meta-Analysis of Interventional Studies. J Sex Med. 2018;15(6):820-38. https:// doi.org/10.1016/j.jsxm.2018.04.641

129. Gianatti EJ, Grossmann M. Testosterone deficiency in men with Type 2 diabetes: pathophysiology and treatment. Diabet Med. 2020;37(2):174-86. https://doi.org/10.1111/dme.13977.

130. Jones TH, Arver S, Behre HM, Buvat J, Meuleman E, Moncada I, et al. Testosterone replacement in hypogonadal men with type 2 diabetes and/or metabolic syndrome (the TIMES2 study). Diabetes Care. 2011;34(4):828-37. https://doi.org/10.2337/dc101233.

131. Hackett G, Cole N, Bhartia M, Kennedy D, Raju J, Wilkinson P, et al. Testosterone replacement therapy improves metabolic parameters in hypogonadal men with type 2 diabetes but not in men with coexisting depression: the BLAST study. J Sex Med. 2014;11(3):840-56. https://doi.org/10.1111/jsm.12404.

132. Kalinchenko SY, Tishova YA, Mskhalaya GJ, Gooren LJ, Giltay EJ, Saad F. Effects of testosterone supplementation on markers of the metabolic syndrome and inflammation in hypogonadal men with the metabolic syndrome: the double-blinded placebo-controlled Moscow study. Clin Endocrinol (Oxf). 2010;73(5):60212. https://doi.org/10.1111/j.1365-2265.2010.03845.x.

133. Aukrust P, Ueland T, Gullestad L, Yndestad A. Testosterone: a novel therapeutic approach in chronic heart failure? J Am Coll Cardiol. 2009;54(10):928-9. https://doi.org/10.1016/j.jacc.2009. 05.039 .

134. Zhao D, Guallar E, Ballantyne CM, Post WS, Ouyang P, Vaidya $\mathrm{D}$, et al. Sex Hormones and Incident Heart Failure in Men and Postmenopausal Women: The Atherosclerosis Risk in Communities Study. J Clin Endocrinol Metab. 2020;105(10). https://doi.org/10.1210/clinem/dgaa500.

135. Luo S, Au Yeung SL, Zhao JV, Burgess S, Schooling CM. Association of genetically predicted testosterone with thromboembolism, heart failure, and myocardial infarction: mendelian randomisation study in UK Biobank. BMJ. 2019;364:1476. https://doi.org/10.1136/bmj.1476.

136. Toma M, McAlister FA, Coglianese EE, Vidi V, Vasaiwala S, Bakal JA, et al. Testosterone supplementation in heart failure: a meta-analysis. Circ Heart Fail. 2012;5(3):315-21. https://doi.org/ 10.1161/CIRCHEARTFAILURE.111.965632.

137. Malkin CJ, Pugh PJ, West JN, van Beek EJ, Jones TH, Channer KS. Testosterone therapy in men with moderate severity heart failure: a double-blind randomized placebo controlled trial. Eur
Heart J. 2006;27(1):57-64. https://doi.org/10.1093/eurheartj/ ehi443.

138. Tao J, Liu X, Bai W. Testosterone Supplementation in Patients With Chronic Heart Failure: A Meta-Analysis of Randomized Controlled Trials. Front Endocrinol (Lausanne). 2020;11:110. https://doi.org/10.3389/fendo.2020.00110.

139. Caminiti G, Volterrani M, Iellamo F, Marazzi G, Massaro R, Miceli M, et al. Effect of long-acting testosterone treatment on functional exercise capacity, skeletal muscle performance, insulin resistance, and baroreflex sensitivity in elderly patients with chronic heart failure a double-blind, placebo-controlled, randomized study. J Am Coll Cardiol. 2009;54(10):919-27. https://doi. org/10.1016/j.jacc.2009.04.078.

140. NCT03518034. A Study to Evaluate the Effect of Testosterone Replacement Therapy (TRT) on the Incidence of Major Adverse Cardiovascular Events (MACE) and Efficacy Measures in Hypogonadal Men ( TRAVERSE ). 2019. https://www. clinicaltrials.gov/ct $2 / \mathrm{show} / \mathrm{NCT} 03518034$ ?term $=$ TRAVERSE \&draw $=2 \&$ rank $=1$.

141. Khera M, Miner M, Jaffe J, Pastuszak AW. Testosterone Therapy and Cardiovascular Risk: A Critical Analysis of Studies Reporting Increased Risk. J Sex Med. 2021;18(1):83-98. https://doi.org/10. 1016/j.jsxm.2020.10.019.

142. Layton JB, Meier CR, Sharpless JL, Sturmer T, Jick SS, Brookhart MA. Comparative Safety of Testosterone Dosage Forms. JAMA Intern Med. 2015;175(7):1187-96. https://doi.org/10.1001/ jamainternmed.2015.1573.

143. Onasanya O, Iyer G, Lucas E, Lin D, Singh S, Alexander GC Association between exogenous testosterone and cardiovascular events: an overview of systematic reviews. Lancet Diabetes Endocrinol. 2016;4(11):943-56. https://doi.org/10.1016/S22138587(16)30215-7.

144. Diem SJ, Greer NL, MacDonald R, McKenzie LG, Dahm P, Ercan-Fang N, et al. Efficacy and Safety of Testosterone Treatment in Men: An Evidence Report for a Clinical Practice Guideline by the American College of Physicians. Ann Intern Med. 2020. https://doi.org/10.7326/M19-0830.

145. Granato S, Barbaro G, Di Giorgio MR, Rossi FM, Marzano C, Impronta F, et al. Epicardial fat: the role of testosterone and lipid metabolism in a cohort of patients with Klinefelter syndrome. Metabolism. 2019;95:21-6. https://doi.org/10.1016/j.metabol. 2019.03.002

146. Neeland IJ, Ross R, Despres JP, Matsuzawa Y, Yamashita S, Shai I, et al. Visceral and ectopic fat, atherosclerosis, and cardiometabolic disease: a position statement. Lancet Diabetes Endocrinol. 2019;7(9):715-25. https://doi.org/10.1016/S2213-8587(19) 30084-1.

147. Ruscica M, Baragetti A, Catapano AL, Norata GD. Translating the biology of adipokines in atherosclerosis and cardiovascular diseases: Gaps and open questions. Nutr Metab Cardiovasc Dis. 2017;27(5):379-95. https://doi.org/10.1016/j.numecd.2016.12. 005.

148. de Bruyne MC, Hoes AW, Kors JA, Hofman A, van Bemmel JH, Grobbee DE. Prolonged QT interval predicts cardiac and all-cause mortality in the elderly. The Rotterdam Study. Eur Heart J. 1999;20(4):278-84. https://doi.org/10.1053/euhj.1998.1276.

149. Pratt CM, Al-Khalidi HR, Brum JM, Holroyde MJ, Schwartz PJ, Marcello SR, et al. Cumulative experience of azimilide-associated torsades de pointes ventricular tachycardia in the 19 clinical studies comprising the azimilide database. J Am Coll Cardiol. 2006;48(3):471-7. https://doi.org/10.1016/j.jacc.2006.04.075.

150. Pecori Giraldi F, Toja PM, Filippini B, Michailidis J, Scacchi M, Stramba Badiale M, et al. Increased prevalence of prolonged QT interval in males with primary or secondary hypogonadism: a pilot study. Int J Androl. 2010;33(1):e132-8. https://doi.org/10.1111/j. 1365-2605.2009.00985.x. 
151. Gagliano-Juca T, Icli TB, Pencina KM, Li Z, Tapper J, Huang G, et al. Effects of Testosterone Replacement on Electrocardiographic Parameters in Men: Findings From Two Randomized Trials. J Clin Endocrinol Metab. 2017;102(5):1478-85. https://doi.org/10.1210/ jc. 2016-3669.

152. Muensterman ET, Jaynes HA, Sowinski KM, Overholser BR, Shen C, Kovacs RJ, et al. Effect of Transdermal Testosterone and Oral Progesterone on Drug-Induced QT Interval Lengthening in Older Men: A Randomized, Double-Blind. Placebo-Controlled Crossover-Design Study. Circulation. 2019;140(13):1127-9. https://doi.org/10.1161/ CIRCULATIONAHA.119.041395.

153. Ridley JM, Shuba YM, James AF, Hancox JC. Modulation by testosterone of an endogenous hERG potassium channel current. J Physiol Pharmacol. 2008;59(3):395-407.

154. Barrett-Connor E, Khaw KT. Endogenous sex hormones and cardiovascular disease in men. A prospective population-based study. Circulation. 1988;78(3):539-45. https://doi.org/10.1161/01.cir. 78.3.539.

155. Araujo AB, O'Donnell AB, Brambilla DJ, Simpson WB, Longcope $\mathrm{C}$, Matsumoto AM, et al. Prevalence and incidence of androgen deficiency in middle-aged and older men: estimates from the Massachusetts Male Aging Study. J Clin Endocrinol
Metab. 2004;89(12):5920-6. https://doi.org/10.1210/jc.2003031719.

156. Haring R, Volzke H, Steveling A, Krebs A, Felix SB, Schofl C, et al. Low serum testosterone levels are associated with increased risk of mortality in a population-based cohort of men aged 20-79. Eur Heart J. 2010;31(12):1494-501. https://doi.org/10.1093/ eurheartj/ehq009.

157. Menke A, Guallar E, Rohrmann S, Nelson WG, Rifai N, Kanarek $\mathrm{N}$, et al. Sex steroid hormone concentrations and risk of death in US men. Am J Epidemiol. 2010;171(5):583-92. https://doi.org/ 10.1093/aje/kwp415.

158. Vikan T, Schirmer H, Njolstad I, Svartberg J. Low testosterone and sex hormone-binding globulin levels and high estradiol levels are independent predictors of type 2 diabetes in men. Eur J Endocrinol. 2010;162(4):747-54. https://doi.org/10.1530/EJE09-0943.

159. Pye SR, Huhtaniemi IT, Finn JD, Lee DM, O'Neill TW, Tajar A, et al. Late-onset hypogonadism and mortality in aging men. J Clin Endocrinol Metab. 2014;99(4):1357-66. https://doi.org/10.1210/ jc.2013-2052.

Publisher's Note Springer Nature remains neutral with regard to jurisdictional claims in published maps and institutional affiliations. 